\title{
Divergence in Labor Market Institutions and International Business Cycles
}

\author{
Raquel Fonseca * $\quad$ Lise Patureau ${ }^{\dagger} \quad$ Thepthida Sopraseuth $\ddagger \S$
}

March 2008

\begin{abstract}
This paper investigates the sources of business cycle comovement within the New Open Economy Macroeconomy framework. It sheds new light on the business cycle comovement issue by examining the role of cross-country divergence in labor market institutions.

We first document stylized facts supporting that heterogeneous labor market institutions are associated with lower cross-country GDP correlations among OECD countries. We then investigate this fact within a two-country dynamic general equilibrium model with frictions on the good and labor markets. On the good-market side, we model monopolistic competition and nominal price rigidity. Labor market frictions are introduced through a matching function à la Mortensen and Pissarides (1999).

Our conclusions disclose that heterogenous labor market institutions amplify the crosscountry GDP differential in response to aggregate shocks. In quantitative terms, they contribute to reduce cross-country output correlation, when the model is subject to real and/or monetary shocks. Our overall results show that taking into account labor market heterogeneity improves our understanding of the quantity puzzle.
\end{abstract}

Keywords: International business cycle, Search, Labor market institutions, Wage bargaining JEL Classification Number : E24, E32, F41

\footnotetext{
*RAND, 1776 Main Street P.O. Box 2138 Santa Monica, CA 90407-2138, USA. e-mail: fonseca@rand.org

†THEMA Université de Cergy-Pontoise, 33, boulevard du Port 95011 Cergy-Pontoise Cedex, France. e-mail: patureau@eco.u-cergy.fr.

${ }^{\ddagger}$ EPEE Université d’Evry and PSE, 4 Bd F. Mitterand, 91025 Evry Cedex, France. e-mail: tsoprase@univevry.fr.

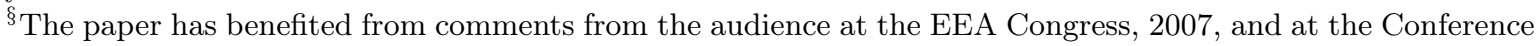
"Labor Market Outcomes, a transatlantic perspective", Paris, 2008. Omissions and mistakes are ours.
} 


\section{Introduction}

One of the most major changes that OECD countries have been facing over the last decades is the increasing liberalization process, both in international trade and in international finance. This so-called "globalization process" is likely to translate into a greater degree of complexity in the interactions between countries, therefore making their business cycles evolve more alike. Somehow unsurprisingly in such a setting, the recent literature demonstrates a vivid interest on the question of the sources of international business cycle comovement.

A large strand of papers have tackled the topic empirically (see Darvas, Rose, and Szarpary (2005), Imbs (2004), Baxter and Kouparitsas (2005) among others). Review of that literature conveys the idea that numerous elements contribute to enhance GDP comovement, without reaching a consensus on the leading determinants. The question has been addressed using theoretical tools as well. The rationalizing of the underlying mechanisms of international business cycles thus lies at the heart of the International Business Cycle (RBC) literature, starting with the seminal paper of Backus, Kehoe, and Kydland (1992). Yet, Dynamic Stochastic General Equilibrium models (DSGE hereafter) that assume flexible prices and wages in the wake of the Real Business Cycle literature have difficulty in replicating the strong positive GDP cross-country correlation (Baxter (1995), Backus, Kehoe, and Kydland (1995)). Hairault (2002) shows the improving performances of introducing labor-market frictions à la Pissarides (1990) in the international RBC model. Furthermore, and in contradiction with the Real Business Cycle paradigm, Kollmann (2001) highlights the role of price and wage rigidities associated with monetary innovations, in explaining international comovement in output. The paper takes part to the debate, adopting an international DSGE model using ingredients of the New Open Economy Macroeconomy framework (Obstfeld and Rogoff (1995)).

The paper sheds new light on the comovement issue by starting from the fact that remarkable differences still exist in national labor and product markets among countries (OECD (2004)). When one wishes to design a "good" model to account for international business cycles, it seems crucial to take into account the specific institutional environment that affects the international propagation of aggregate shocks. Within OECD countries, one most documented divergence is tied to the labor market functioning. This paper investigates its role in business cycle comovement, by including labor market institutions in a two-country DSGE model.

The role of divergence in labor market institutions in international fluctuations has hardly been explored in the DSGE literature. Campolmi and Faia (2006) and Poilly and Sahuc (2008) are recent notable exceptions. Poilly and Sahuc (2008) investigate the role of labor markets heterogeneity within a monetary union, focusing on the welfare effects of labor markets reforms. Campolmi and Faia (2006) point out that cross-country differences in labor market institutions (LMI hereafter) are major driving forces behind the pronounced inflation differentials observed in Europe. Our paper is closer to Campolmi and Faia's (2006), in that it focuses on the positive 
implications of asymmetric LMI on international fluctuations. We differentiate from them in several issues. The first originality of our work lies in our focus on GDP comovement and the analysis of non-trivial effects of heterogenous labor markets on output dynamics, rather than on inflation dynamics. Second, we analyze the role of this heterogeneity in accounting for GDP comovement across OECD countries in a flexible exchange rate regime, rather than across European countries within a monetary union.

Empirical evidence suggests heterogeneity in labor market regulation does indeed matter. Blanchard and Wolfers (2000) make a seminal contribution on that point regarding employment performances among OECD countries. Based on a panel of 20 OECD countries since 1960, they show that the interaction between country-specific aggregate shocks and labor market institutions is crucial to account for the heterogeneity in employment performances observed in the data. More closely related to the GDP comovement issue, Fonseca, Patureau, and Sopraseuth (2007) show that divergence in labor market institutions significantly reduces the cross-country GDP correlation among OECD countries over the period 1964-1999, even after controlling for a number of explanatory variables. Hence, large differences in labor market regulations have to be taken into account when one investigates business-cycle comovement.

These empirical results call for some theoretical investigation. This is the route we pursue in the paper, focusing on the theoretical link between divergence in labor market institutions and international business-cycle comovement. As a first step, we present stylized facts supporting the negative link between heterogeneity in labor market regulations across OECD countries, and the extent of their business cycle synchronization. The aim is then to rationalize the underlying mechanisms in a dynamic stochastic general equilibrium model. Our focus on OECD countries leads us to model two countries in a flexible exchange rate regime, that differ from their labor market functioning, i.e. with different strictness of the labor markets. We thus ask for the positive implications of asymmetric labor market institutions in this theoretical setting.

The main results of the paper may be summarized as follows. First, cross-country divergence in labor market institutions substantially matters in affecting GDP responses to aggregate shocks. It generates asymmetric responses of macroeconomic aggregates (namely, employment and output) to a common aggregate shock, either technological or monetary. GDP differential is mostly attributable to more limited responses in the country featured with more stringent labor market institutions (i.e., France versus the USA). In both cases of supply and demand shocks, the instantaneous effects on GDP differential, coming from divergence in the amount of negotiated worked hours, are filled in by persistent differences in the dynamics of job flows the periods after the shock, implying persistent cyclical GDP differentials. Second, interactions between aggregate shocks and heterogenous labor market institutions substantially affects the extent of business cycle synchronization. Cross-country GDP correlation is found to be lower when labor market institutions differ across countries, either when the model is subject to technological or 
monetary shocks. Consistently with empirical evidence, the results suggest that divergence in the labor market functioning matters if one is willing to understand the sources of international comovement among OECD countries.

The paper is organized as follows. Using data on a sample of 15 OECD countries, Section 2 provides empirical evidence of the negative link between divergence in labor market institutions and business cycle synchronization. The following sections investigate this relation using a DSGE model inscribed in the New Open Economy Macroeconomy framework. Section 3 presents the building blocks of the model. Section 4 presents the calibration of the model, and particularly the way it captures asymmetries in labor market institutions between a "rigid LMI" country and a "flexible LMI" country. We then investigate the role of asymmetries in the labor market institutions in international business cycles. In Section 5, we evaluate how they affect the crosscountry GDP differential that follows a technological shock and a monetary shock. In Section 6, we derive quantitative results that confirm the role of asymmetric labor markets in reducing the cross-country GDP correlation. Finally, Section 7 concludes.

\section{Stylized facts}

To what extent heterogeneity across OECD labor markets may affect the extent of their business cycle synchronization? This section presents some stylized facts that evaluate the relation between both elements. Anticipating the results, it illustrates some empirical evidence that crosscountry divergence in labor market institutions exerts a negative impact on GDP comovement among OECD countries.

\subsection{Data description and methodology}

We capture international business cycle comovement by the cross-country GDP correlation (denoted $\rho^{y}$ ), as standard in the international business cycle literature. We use quarterly data over 15 OECD countries, over the period 1973:2-1998:4. Cross-country GDP correlation is calculated over the whole period, for all country-pairs, after GDP series have been filtered using the Hodrick and Prescott (1997) filter. This gives us 105 cross-country GDP correlations.

Cross-country divergence in the labor market institutions is captured as follows. We want to dispose of a variable that represents the overall "rigidity" of the labor market (in each of the countries considered). Starting from the fact that labor market regulation covers multiple dimensions, this raises the question of which LMI dimensions to consider. We retain those that are usually considered in the labor market literature (Nickell (1998), Belot and Van Ours (2004) among others), i.e. employment protection degree (EPL hereafter), union density and union coverage, both intended to capture unions' bargaining power, the benefit replacement ratio and tax wedge. The higher the variable, the more stringent labor market regulation. After taking the mean value over the period for each LMI variable, we build a country-specific synthetic LMI 
indicator $^{1}$ that averages them. We also calculate the mean value of EPL over the period (per country). We then build the variables capturing the cross-country divergence in the labor market institutions. They are respectively given by the absolute difference of the synthetic LMI indicator (denoted "Diff. in LMI" hereafter) and of the EPL indicator (denoted "Diff. in EPL") between each country pair. As such, the higher the value in a pair $(i, j)$, the more divergent LMI across countries $i$ and $j$.

To gauge robustness in the relation between divergence in labor market institutions and GDP comovement, we use control variables that are likely to affect the extent of GDP comovement. However, even though largely investigated empirically (see Baxter and Kouparitsas (2005), Darvas, Rose, and Szarpary (2005), Imbs (2001) among others), there is no consensus over the key determinants of international business-cycles comovement. We consider here gravity variables (precisely, a dummy indicating that the two countries of the pair have the same language, denoted "Common lang.") and the extent of bilateral trade between the two countries of the pair ("Bilat. trade"), as most related papers underline their role in enhancing business-cycles comovement (Baxter and Kouparitsas (2005)). Details on the database and the variables sources are given in Appendix A.

\subsection{Empirical results}

Does divergence in labor market institutions reduce business-cycle synchronization? We first investigate the link by using descriptive statistics. Table 1 displays the correlation of the explicative variables with the cross-country GDP correlation.

Table 1: Correlation with $\rho^{y}$

\begin{tabular}{c|cccc}
\hline \hline & Diff. in LMI & Diff. in EPL & Common lang. & Bilat. trade \\
$\rho^{y}$ & $-0.325^{a}$ & $-0.235^{b}$ & $0.272^{a}$ & $0.374^{a}$ \\
\hline \hline
\end{tabular}

Table 1 reports that the correlation between divergence in LMI and business cycle comovement is negative, and significant, for both the synthetic indicator and employment protection. The other correlations have the expected sign as well. The fact that the country pair shares the same language, and have large bilateral trade flows, significantly enhance their business cycle synchronization, consistently with Baxter and Kouparitsas (2005) and Frankel and Rose (1998).

We illustrate further the relation between divergence in LMI and GDP comovement, by running OLS regression according to the benchmark equation:

$$
\rho_{i j}^{y}=\alpha+\beta X_{i j}+\gamma Y_{i j}+\varepsilon_{i j}
$$

\footnotetext{
${ }^{1}$ Nevertheless, while tax wedge, union density, union coverage and the benefit replacement ratio are all constructed as percentages, the Employment Protection Laws variable is an indicator that takes discrete values. Consequently, we exclude employment protection when building the synthetic indicator, to consider it per se.
} 
with $X_{i j}$ our measure of divergence in LMI (either "Diff. in LMI" or "Diff. in EPL") ${ }^{2}, Y_{i j}$ control variables (common language dummy and/or bilateral trade), $\varepsilon_{i j}$ the residual with standard properties (mean equal to 0 and uncorrelated with itself) and $\alpha$ a constant. Regressions are reported in Table 2. Based on previous descriptive statistics analysis, we expect that the estimated parameters $\beta$ and $\gamma$ are negative and positive respectively.

Table 2: OLS regression results

\begin{tabular}{l|cccc|cccc}
\hline \hline & \multicolumn{7}{|c}{ Dependent variable: $\rho^{y}$} \\
\cline { 2 - 9 } & $(\mathrm{A})$ & $(\mathrm{B})$ & $(\mathrm{C})$ & $(\mathrm{D})$ & $(\mathrm{E})$ & $(\mathrm{F})$ & $(\mathrm{G})$ & $(\mathrm{H})$ \\
\hline Diff. in LMI & $-0.006^{a}$ & $-0.006^{a}$ & $-0.004^{b}$ & $-0.005^{a}$ & & & & \\
Diff. in EPL & & & & & $-0.149^{b}$ & $-0.139^{b}$ & $-0.118^{b}$ & $-0.114^{b}$ \\
Common lang. & & $0.204^{a}$ & & $0.162^{b}$ & & $0.182^{a}$ & & $0.133^{b}$ \\
Bilat. trade & & & $0.018^{a}$ & $0.014^{b}$ & & & $0.021^{a}$ & $0.018^{a}$ \\
\hline $\mathrm{N}$ & 105 & 105 & 105 & 105 & 105 & 105 & 105 & 105 \\
$R^{2}$ & 0.11 & 0.19 & 0.19 & 0.24 & 0.06 & 0.12 & 0.17 & 0.21 \\
\hline \multicolumn{7}{l}{ Note: ${ }^{a}$ significant at $1 \%,{ }^{b}$ significant at $5 \%$} \\
\hline \hline
\end{tabular}

Columns (A) to (D) report regression results when "Diff. in LMI" is used as the measure of cross-country labor markets heterogeneity, while we consider "Diff. in EPL" instead in columns (E) to (H). Results reported in column (A) show that divergence in labor market institutions significantly reduces the extent of GDP comovement, since the estimated coefficient is significantly negative (even if very low). The result is robust to the inclusion of control variables, as shown in columns (B) to (D). Coefficients associated with control variables appear correctly signed and statistically significant. Results reported in columns (E) to (H) also yield the conclusion that divergence in employment protection significantly reduces cross-country GDP correlation.

It is worth noticing that the explicative power of the regression is weak, as indicated by the low values of $R^{2}$ in Table 2. Nevertheless, we do not consider this empirical analysis as an attempt to account for the whole sources of international comovement. Rather, the aim is to evaluate the link between heterogeneity in labor market institutions and business cycle synchronization among OECD countries. Regression results reported in Table 2 give empirical support to the fact that divergent labor market institutions across OECD countries significantly reduce the extent of their business cycle comovement. These results are consistent with those obtained by Fonseca, Patureau, and Sopraseuth (2007). Using data panel analysis on OECD countries, they get that countries with similar labor markets tend to have more synchronized business cycles. The objective is now to account for such a relation and its underlying economic mechanisms in a DSGE model.

\footnotetext{
${ }^{2}$ We do not include both variables in the same regression because they are highly correlated, raising multicollinearity problems.
} 


\section{A two-country model with labor market institutions}

\subsection{Description of the model}

We develop a two-country intertemporal general equilibrium model, in the vein of the New Open Economy Macroeconomy framework à la Obstfeld and Rogoff (1995). In an international DSGE model, Kollmann (2001) underlines the key role of monetary shocks in presence of nominal price rigidity in accounting for cross-country GDP correlation. Accordingly, we assume that on the good-market side, firms are in monopolistic competition in the production of differentiated varieties. Nominal price rigidity is modeled through quadratic adjustment costs on prices (Rotemberg (1982)). Besides, as in Hairault (2002) and Campolmi and Faia (2006), the labor market features matching frictions à la Pissarides (1990). This allows to study equilibrium unemployment in a non-Walrasian economy, and to provide a rich dynamics for the formation and dissolution of employment relations. Wages and hours are assumed to be the result of an efficient Nash-bargaining process between firms and workers, as in Andolfatto (1996), Chéron and Langot (2004) or Hairault (2002) (among others). Performances in employment, hence in output are thus directly affected by the labor market institutions in place. Such a setting consequently allows to ask for the role of asymmetric labor market institutions in affecting international GDP comovement.

\subsection{The search process on the labor market}

Let $N_{i t}$ and $V_{i t}$ respectively denote the number of workers and the total number of new jobs made available by firms in country $i$, period $t$. The law of motion for aggregate employment is defined as:

$$
N_{i t+1}=\left(1-s_{i}\right) N_{i t}+H_{i t}
$$

with $0<s_{i}<1$ the exogenous separation rate of job-worker pair in country $i$, and $H_{i t}$ the number of hirings per period, which is determined by a conventional constant returns-to-scale matching technology à la Pissarides (1990):

$$
H_{i t}=\chi_{i} V_{i t}^{\psi}\left(1-N_{i t}\right)^{1-\psi}
$$

with total labor force normalized to 1 . The parameter $0<\psi<1$ measures the bargaining power of firms in the Nash negotiation process. $\chi_{i}>0$ is a scale parameter measuring the "efficiency" of the matching function. Due to the time-consuming nature of search on the labor market, a job vacancy can at best become productive only one period after time has slipped by.

Defining $\phi_{i t}=\frac{H_{i t}}{1-N_{i t}}$ as the probability to find a job for unemployed workers, the law of motion of employment in country $i$ can be re-written as:

$$
N_{i t+1}=\left(1-s_{i}\right) N_{i t}+\phi_{i t}\left(1-N_{i t}\right)
$$




\subsection{The program of the agents}

\subsubsection{The households}

In each country, households consume a continuum of differentiated goods, either produced locally or imported. As frequent in the RBC labor market literature (Andolfatto (1996) among others), we assume complete income insurance markets. Consequently, the optimal households' behavior is derived using a dynamic program where ex-post heterogeneity on the labor market does not matter: risk-averse households insure themselves fully against heterogeneous wealth positions. ${ }^{3}$ We thus derive the optimal workers' decision rules by solving the program of a representative household. The country $i$ representative maximizes her expected intertemporal utility:

$$
E_{0}=\sum_{t=0}^{\infty} \beta^{t} U\left(C_{i t}^{c}, h_{i t}\right) \quad i=1,2
$$

$C_{i t}^{c}$ is the aggregate bundle of consumption (defined below) and $h_{i t}$ denotes worked hours supplied by the agent. The instantaneous utility function is specified as:

$$
U\left(C_{i t}^{c}, h_{i t}\right)=\log \left(C_{i t}^{c}\right)+N_{i t} \kappa_{i}^{n} \frac{\left(1-h_{i t}\right)^{1-\xi}}{1-\xi} \quad i=1,2
$$

where the first term is the utility from final good consumption, while the second part represents the disutility from work by supplying $h_{i t}$ units of hours (total time endowment being normalized to unity). $\xi$ is the inverse of the intertemporal elasticity of substitution of leisure, while $\kappa_{i}^{n}$ measures the relative utility of leisure. $N_{i t}$ jobs are productive at the beginning of period $t$, which represents the probability of employment for each household's member.

In what follows, we present the optimizing program in country 1. Country 2's program can be inferred by symmetry.

The intratemporal program In each country, the consumption bundle $C_{i t}^{c}$ aggregates across differentiated varieties produced by domestic and foreign firms. Following a large bulk of related papers (Kollmann (2001) among others), we assume that the elasticity of substitution between goods is lower between domestic and foreign varieties, than between two national varieties.

The consumption bundle $C_{1 t}^{c}$ is specified according to the following CES specification:

$$
C_{1 t}^{c}=\left[\kappa^{\frac{1}{\zeta}} C_{1 t}^{\frac{\zeta-1}{\zeta}}+(1-\kappa)^{\frac{1}{\zeta}} C_{2 t}^{\frac{\zeta-1}{\zeta}}\right]^{\frac{\zeta}{\zeta-1}}
$$

with $0<\kappa<1$ and $\zeta \geq 1$. $C_{1 t}$ denotes domestic consumption of the local variety, $C_{2 t}$ domestic consumption of the foreign variety, with $(1-\kappa)$ the share of imported goods. $\zeta$ is the

\footnotetext{
${ }^{3}$ As notably underlined by Trigari (2004), this is equivalent to consider a "big" family whose members, employed and unemployed, pool their incomes to maximize the expected life-time utility of the representative household. For further details see Andolfatto (1996).
} 
elasticity of substitution between domestic and foreign varieties. Each national variety is made of differentiated goods, according to the following equation:

$$
\begin{aligned}
C_{1 t} & =\left[\int_{0}^{1}\left[c_{1 t}(z)\right]^{\frac{\eta-1}{\eta}} d z\right]^{\frac{\eta}{\eta-1}} \\
C_{2 t} & =\left[\int_{0}^{1}\left[c_{2 t}(z)\right]^{\frac{\eta-1}{\eta}} d z\right]^{\frac{\eta}{\eta-1}}
\end{aligned}
$$

where $\eta>1$ represents the elasticity of substitution of goods within a national variety. It is assumed that $\eta>\zeta . c_{1 t}(z)$ is the domestic consumption of a variety $z$ produced by a firm located in country $1, c_{2 t}(z)$ that of a variety $z$ produced by a firm located in country 2 . In each country, we assume a continuum of differentiated firms over the range $[0,1]$. The standard solving of the intratemporal program of the households is detailed in Appendix B.

The intertemporal program Each period, the domestic household faces two constraints, a cash-in-advance constraint (equation (8)) and a budget constraint (equation 9)).

$$
\begin{gathered}
P_{1 t}^{c} C_{1 t}^{c}\left(1+\tau_{1}^{c}\right) \leq M_{1 t} \\
P_{1 t}^{c} C_{1 t}^{c}\left(1+\tau_{1}^{c}\right)+M_{1 t+1}+B_{1 t+1}+P_{1 t}^{c} C A_{1 t} \\
\leq N_{1 t} w_{1 t} h_{1 t} P_{1 t}^{c}\left(1-\tau_{1}^{d}\right)+\left(1-N_{1 t}\right) b_{1 t}+B_{1 t}\left(1+i_{t}\right)+M_{1 t}+T_{1 t}+\int_{0}^{1} \Pi_{1 t}(z) d z
\end{gathered}
$$

As shown by equation (8), money is introduced in the model though a cash-in-advance constraint on consumption purchases, with $C_{1 t}^{c}$ consumption and $P_{1 t}^{c}$ the consumption price index, taking into account the (country-specific) consumption tax rate $\tau_{1}^{c}$. The budget constraint of the domestic household is reported in equation (9). As in Christoffel and Linzert (2005), we assume that when employed, household members receive the wage payments $w_{1 t} h_{1 t}$, net of direct taxes $\left(\tau_{1}^{d}\right)$, while when unemployed they receive unemployment benefits which are evaluated in consumption units, $b_{1 t} .{ }^{4}$ The household's resources are also made of the detention of financial assets. We retain the assumption of incomplete international financial markets, as a large strand of the related literature underlines the role of this assumption in the international transmission of shocks (Ghironi (2006) or Duarte and Stockman (2005)). Each period, a no-risk interest rate bond is issued in domestic currency; when subscribed in period t, it yields a no-risk nominal interest rate $i_{t}$ in $t+1$. The household enters the period with an initial stock of money $M_{1 t}$ and receives transfers from the government $T_{1 t}$. Last, the household perceives the end-of-period profits as the owner of the local firms $\left(\int_{0}^{1} \Pi_{1 t}(z) d z\right)$.

\footnotetext{
${ }^{4}$ One can also interpret $b_{i t}$ as home production of a non-tradable good. We favor the interpretation in terms of unemployment insurance, whom we will make use of in our calibration.
} 
As discussed by Ghironi (2006), the introduction of incomplete asset markets alters the property of stationarity of the model, since temporary shocks have permanent effects on macroeconomic variables. Recent related literature proposes alternative ways of avoiding non-stationarity. We follow Kollmann (2004), by assuming that the household faces adjustment costs when increasing her stock of international assets. These costs are paid in terms of composite good and are scaled by the parameter $\Phi_{b}>0$, according to: ${ }^{5}$

$$
C A_{1 t}=\frac{\Phi_{b}}{2}\left[\frac{B_{1 t+1}}{P_{1 t}^{c}}\right]
$$

The period's resources are used for consumption (given the consumption tax rate $\tau_{1}^{c}$ ), demand for nominal balances $M_{1 t+1}$ and financial international assets $B_{1 t+1}$, taking into account adjustment costs on these assets.

As detailed below, each period worked hours and wage (before tax) $\left\{h_{1 t}, w_{1 t}\right\}$ are the Nashbargaining result of negotiations between firms and workers. When solving the intertemporal program, the household consequently takes them as given. She maximizes equation (4) subject to her cash-in-advance constraint (8) and her budget constraint (9). Multipliers associated with each constraint are denoted $\vartheta_{1 t}$ and $\lambda_{1 t}$ respectively. The optimization program is written as a Bellman equation:

$$
\mathcal{V}\left(\mathcal{S}_{1 t}^{H}\right)=\max _{\left\{C_{1 t}^{c}, M_{1 t+1}, B_{1 t+1}\right\}}\left\{U\left(C_{1 t}^{c}, h_{1 t}\right)+\beta E_{t} V\left(\mathcal{S}_{1 t+1}^{H}\right)\right\}
$$

with the household's state variables $\mathcal{S}_{1 t}^{H}=\left\{M_{1 t}, N_{1 t}, B_{1 t}\right\}$. First-order conditions with respect to consumption, nominal bonds and money holdings are respectively:

$$
\begin{aligned}
U_{c 1 t}^{\prime} & =\left(1+\tau_{1}^{c}\right) P_{1 t}^{c}\left(\lambda_{1 t}+\vartheta_{1 t}\right) \\
\lambda_{1 t}\left(1+\Phi_{b} \frac{B_{1 t+1}}{P_{1 t}^{c}}\right) & =\beta E_{t}\left[\lambda_{1 t+1}\left(1+i_{t+1}\right)\right] \\
\lambda_{1 t} & =\beta E_{t}\left[\frac{U_{c 1 t+1}^{\prime}}{P_{1 t+1}^{c}\left(1+\tau_{1}^{c}\right)}\right]
\end{aligned}
$$

Equation (10) represents the optimal choice for consumption: the marginal utility of consumption $\left(U_{c 1 t}^{\prime}\right)$ is set equal to its marginal cost, that is a budget cost $\left(P_{1 t}^{c} \lambda_{1 t}\right)$ plus the requirement of having money holdings $\left(P_{1 t}^{c} \vartheta_{1 t}\right)$, given consumption taxes. Equation (11) represents the optimal demand for financial assets, such as the marginal cost (left-side of equation (11)) is equal to the marginal benefit, that is the expected increase in real wealth given future interest rate (right-side of the equation). Equation (12) states the optimal money demand: the cost of one marginal unit of money $\left(\lambda_{1 t}\right)$ equates its expected future marginal benefit, that is the expected gain in terms of marginal utility of consumption, given the purchasing power of money in the $t+1$ period and consumption tax rate.

\footnotetext{
${ }^{5}$ Schmitt-Grohe and Uribe (2003) investigate the quantitative differences implied by alternative approaches in the literature to induce stationarity. They find that all versions deliver virtually identical dynamics at business cycle frequencies.
} 


\subsubsection{Firms}

The profit-maximizing program of an individual firm In a monopolistic competition setting, each firm $z$ (in country $i$ ) sets its sale price $p_{i t}(z)$ and quantity $y_{i t}(z)$, taking consumption price indices and aggregate demand functions as given. Nominal rigidities are incorporated as in Rotemberg (1982), by assuming quadratic costs on adjusting prices. For a country $i$ firm $z$, adjustment cost on prices is written similar to Ireland (2001):

$$
c p_{i t}(z)=\frac{\Phi_{P}}{2}\left(\frac{p_{i t}(z)}{p_{i t-1}(z)}-\pi_{i}\right)^{2} y_{i t}(z) \quad \Phi_{P}>0
$$

As $\pi_{i}$ represents the steady-state gross inflation rate in country $i$, adjustment costs are null at the long term equilibrium. Price adjustment costs are paid in terms of composite good. To preserve homogeneity of demand functions, they are assumed to have the same structure as the consumption one (as well as the other good-demand motives, as detailed below).

The firm also invests in physical capital $k_{i t}(z)$, facing quadratic adjustment costs on capital. The law of motion for the firm $z$ physical stock is given by the standard equation:

$$
k_{i t+1}(z)=(1-\delta) k_{i t}(z)+i_{i t}^{c}(z)
$$

with $i_{i t}^{c}(z)$ the investment bundle of firm $z$ and $0<\delta<1$ the depreciation rate. Adjustment costs on capital (paid in terms of composite good) are specified as in Ireland (2001):

$$
c i_{i t}(z)=\frac{\Phi_{I}}{2} \frac{\left[k_{i t+1}(z)-k_{i t}(z)\right]^{2}}{k_{i t}(z)}
$$

with $\Phi_{I}>0$. Last, labor-market frictions require firms to post vacant jobs $\left(v_{i t}(z)\right)$, at the cost $\omega_{i}$ per vacant job (in terms of the composite good as well).

Technologies are identical across countries (up to asymmetrical technological shocks) and across firms. Production of good $z$ requires capital and labor, given the following Cobb-Douglas technology:

$$
y_{i t}(z)=A_{i t} k_{i t}(z)^{\alpha}\left[n_{i t}(z) h_{i t}(z)\right]^{1-\alpha} \quad i=1,2
$$

with $0<\alpha<1$. $k_{i t}(z)$ is the capital stock, $n_{i t}(z)$ labor force and $h_{i t}(z)$ worked hours in firm $z$. $A_{i t}$ designs the technology level in country $i$. It is assumed to follow a joint first-order autoregressive stochastic process:

$$
\begin{aligned}
& \log A_{1 t+1}=\rho_{a} \log A_{1 t}+\rho_{a 12} \log A_{2 t}+\left(1-\rho_{a}-\rho_{a 12}\right) \log \bar{A}+\varepsilon_{1, t+1}^{a}+\psi_{a} \varepsilon_{2 t+1}^{a} \\
& \log A_{2 t+1}=\rho_{a} \log A_{2 t}+\rho_{a 12} \log A_{1 t}+\left(1-\rho_{a}-\rho_{a 12}\right) \log \bar{A}+\varepsilon_{2, t+1}^{a}+\psi_{a} \varepsilon_{1 t+1}^{a}
\end{aligned}
$$

where $\log \bar{A}$ is the mean of the process and $\left\{\varepsilon_{i}^{a}\right\}_{t}$ is the vector of technological innovations serially independent in country $i$, with $E\left[\varepsilon_{1}^{a}\right]=E\left[\varepsilon_{2}^{a}\right]=0$. We adopt a general specification by allowing some cross-country correlation in the technological processes through $\rho_{a 12}$. Besides, technological innovations are correlated across countries through $\psi_{a}$. 
Each country $i$ firm $z$ faces a demand function for its goods emanating from each country. For a country 1 firm $z$, it is given by:

$$
y_{1 t}^{d}(z)=\left[\frac{p_{1 t}(z)}{P_{1 t}}\right]^{-\eta} D_{1 t}+\left[\frac{p_{1 t}^{*}(z)}{P_{1 t}^{*}}\right]^{-\eta} D_{1 t}^{*}
$$

with $D_{1 t}$ demand for the domestic variety coming from domestic agents, and $D_{1 t}^{*}$ demand for domestic variety coming from the foreign ones. $p_{1 t}(z)$ is the price of the domestic good $z, P_{1 t}$ and $P_{1 t}^{*}$ are the prices of the bundle of domestic varieties in the home and foreign countries respectively.

Extending equation (32) to other good-demand motives, both domestic and foreign demand for domestic variety can be expressed as function of aggregate demands $\left(D_{i t}^{c}\right)$. Demand for good $z$ produced in country 1 can then be re-written as:

$$
y_{1 t}^{d}(z)=\left[\frac{p_{1 t}(z)}{P_{1 t}}\right]^{-\eta}\left[\kappa\left(\frac{P_{1 t}}{P_{1 t}^{c}}\right)^{-\theta} D_{1 t}^{c}+(1-\kappa)\left(\frac{P_{1 t}}{e_{t} P_{2 t}^{c *}}\right)^{-\theta} D_{2 t}^{c}\right]
$$

$P_{i t}^{c}$ is the consumption price index in country $i=1,2$, whose expressions are detailed in Appendix B. Aggregate demand in country $i$ is given by:

$$
D_{i t}^{c}=C_{i t}^{c}+I_{i t}^{c}+\omega_{i} V_{i t}+C I_{i t}+C P_{i t}+C A_{i t}
$$

Aggregate investment $I_{i t}^{c}$ is defined as $\int_{0}^{1} i_{i t}^{c}(z) d z$. Aggregate adjustment costs on capital $\left(C I_{i t}\right)$ and on prices $\left(C P_{i t}\right)$ are similarly defined, as well as $\omega_{i} V_{i t}$, that represents the demand of goods devoted to job posting in country $i$.

Since we will consider a symmetric equilibrium across firms, we discard notations specific to firm $z$, by suppressing the $z$ index to ease the reading. By convention, lowercase refers to one firm, uppercase to aggregate variables. Each individual firm chooses a contingency plan for the set of control variables, that maximizes the expected discounted value of the dividend flow. Defining its vector of control variables as $\mathcal{C}_{1 t}^{F}=\left\{v_{1 t}, k_{1 t+1}, n_{1 t+1}, p_{1 t}, y_{1 t}\right\}$ and that of state variables as $\mathcal{S}_{1 t}^{F}=\left\{k_{1 t}, n_{1 t}\right\}$, the dynamic problem of each individual firm in country 1 is written recursively as follows:

$$
\mathcal{W}\left(\mathcal{S}_{1 t}^{F}\right)=\max _{\mathcal{C}_{1 t}^{F}}\left\{\begin{array}{c}
p_{1 t} y_{1 t}-P_{1 t}^{c} w_{1 t} h_{1 t} n_{1 t}\left(1+\tau_{1}^{f}\right)-P_{1 t}^{c} i_{1 t}^{c}(z) \\
-\omega_{1} P_{1 t}^{c} v_{1 t}-P_{1 t}^{c}\left[c p_{1 t}+c i_{1 t}\right]+\beta E_{t}\left[\frac{\lambda_{1 t+1}}{\lambda_{1 t}} \mathcal{W}\left(\mathcal{S}_{1 t+1}^{F}\right)\right]
\end{array}\right\}
$$

subject to the technological constraint (14), the demand function (17), the law of motion of physical capital (13), and that of labor force given by:

$$
n_{1 t+1}=\left(1-s_{1}\right) n_{1 t}+q_{1 t} v_{1 t}
$$

$q_{i t}=\frac{H_{i t}}{V_{i t}}$ is the probability that a vacant job is matched in country $i=1,2.0<\tau_{i}^{f}<1$ is the employer's labor tax rate. As domestic firms are hold by the representative household, the 
discounted rate is the ratio of the multipliers associated with the budget constraint, since that ratio reflects the consumer's variation in wealth. Let us also define $z_{1 t}$ and the Tobin's $q_{1 t}^{T}$ as:

$$
\begin{aligned}
z_{1 t} & =\frac{1}{1+\mu_{1 t}} \frac{p_{1 t}}{P_{1 t}^{c}} \alpha \frac{y_{1 t}}{k_{1 t}} \\
q_{1 t}^{T} & =1+\Phi_{I} \frac{i_{1 t}^{c}-\delta k_{1 t}}{k_{1 t}}
\end{aligned}
$$

with $\mu_{1 t}$ the mark-up rate over marginal cost (see Appendix B for details). First-order conditions yield the following system:

$$
\begin{gathered}
q_{1 t}^{T}=\beta E_{t}\left[\frac{\Lambda_{1 t+1}}{\Lambda_{1 t}}\left\{z_{1 t+1}+q_{1 t+1}^{T}-\delta+\frac{\Phi_{I}}{2}\left(\frac{i_{1 t+1}-\delta k_{1 t+1}}{k_{1 t+1}}\right)^{2}\right\}\right] \\
\frac{\omega_{1}}{q_{1 t}}=\beta E_{t}\left[\frac{\Lambda_{1 t+1}}{\Lambda_{1 t}}\left\{\frac{1}{1+\mu_{1 t+1}} \frac{p_{1 t+1}}{P_{1 t+1}^{c}}(1-\alpha) \frac{y_{1 t+1}}{n_{1 t+1}}-w_{1 t+1} h_{1 t+1}\left(1+\tau_{1}^{f}\right)+\left(1-s_{1}\right) \frac{\omega_{1}}{q_{1 t+1}}\right\}\right]
\end{gathered}
$$

$$
y_{1 t}+\beta E_{t}\left[\frac{\Lambda_{1 t+1}}{\Lambda_{1 t}} \Phi_{P} \frac{p_{1 t+1}}{p_{1 t}}\left(\frac{p_{1 t+1}}{p_{1 t}}-\pi_{1}\right) y_{1 t+1}\right]=\eta \frac{\nu_{1 t}}{p_{1 t}} y_{1 t}+\Phi_{P} \frac{P_{1 t}^{c}}{p_{1 t-1}}\left(\frac{p_{1 t}}{p_{1 t-1}}-\pi_{1}\right) y_{1 t}
$$

with $\Lambda_{1 t} \equiv P_{1 t}^{c} \lambda_{1 t}$ the domestic household's marginal utility of wealth in real terms, and $\nu_{1 t}$ the multiplier associated with the demand function (17).

Equation (19) represents the optimal choice of capital accumulation. Firms invest in physical capital until the cost of investment $\left(q_{1 t}^{T}\right)$ equals the expected return on investment, which is given by the expected resell price of capital, lower than the true marginal productivity by the mark-up rate. Equation (20) highlights the trade-off faced by firms regarding job posting. Firms are enticed to post vacant jobs such as the cost of posting $\left(\frac{\omega_{1}}{q_{1 t}}\right)$ is equal to the expected return of a match. As well as in equation (19), the expected marginal return of employment is lower than the true marginal productivity, given the mark-up rate the monopolistic firm can extract. Last, equation (21) gives the optimal pricing decision of the firm. Absent nominal price rigidity $\left(\Phi_{P}=0\right)$, the mark-up rate is constant, equal to $\mu=\frac{1}{\eta-1}$. As long as firms face adjustment costs on prices $\left(\Phi_{P}=0\right)$ mark-up rates are endogenous and fluctuate following nominal and real perturbations.

Aggregating across firms Given the assumption of symmetry across firms within a country, the aggregate level of capital stock $K_{i t}$, employment $N_{i t}$, vacancies $V_{i t}$ and output $Y_{i t}$ in each country $i=\{1,2\}$ are defined as follows:

$$
\begin{aligned}
K_{i t} & =\int_{0}^{1} k_{i t}(z) d z=k_{i t} & V_{i t} & =\int_{0}^{1} v_{i t}(z) d z=v_{i t} \\
N_{i t} & =\int_{0}^{1} n_{i t}(z) d z=n_{i t} & Y_{i t} & =\int_{0}^{1} y_{i t}(z) d z=y_{i t}
\end{aligned}
$$


From now on, we consider aggregate variables in the reasoning, eventually adapting equations to that aim. In particular, the Nash-bargaining program will be solved by considering that surplus from matches are shared by the representative household on the one hand, and the representative "aggregate" firm on the other hand.

\subsubsection{Negotiating the labor contract}

Each period, the labor contract stipulating the real wage $\left(w_{i t}\right)$ and the number of worked hours $\left(h_{i t}\right)$ is bargained between firms and employed workers according to the Nash criterion. Before detailing further the bargaining process, let us underline two points. First, as previously mentioned, we solve the program considering a representative firm, after imposing symmetry across monopolistic atomistic firms. Henceforth, the bargaining process may be considered as taking place at the centralized level. Consequences of wage bargaining on employment at the national level are fully internalized. ${ }^{6}$

Second, we retain the efficient Nash-bargaining process framework, where both wage and worked hours are negotiated, versus the "right-to-manage" setting. The right-to-manage setting (where only the real wage is negotiated and firms freely choose hours) is found to better reproduce persistence in wage and inflation dynamics by Christoffel and Linzert (2005) and Christoffel, Küster, and Linzert (2006). Since these are not our primary focus, we rather adopt the efficient Nash-bargaining framework, following so the large bulk of papers in the related literature (see Hairault (2002), Chéron and Langot (2004), Trigari (2004) or Campolmi and Faia (2006) among others).

To solve the Nash bargaining, we need first to derive the marginal values of a match for both players (firms and workers), as they will enter the sharing rule of the bargaining process. The solving of the Nash-bargaining closely follows Chéron and Langot (2004). We consequently do not come into much detail in the technical solving of the optimal contract here. It is described in Appendix B. In what follows, we present the solution of the Nash-bargaining process in country 1 , that in country 2 can be derived by symmetry.

In country 1 , the optimal contract with respect to hours and wage satisfies the following equations:

$$
\begin{gathered}
\frac{\kappa_{1}^{n}}{\lambda_{1 t}}\left(1-h_{1 t}\right)^{-\xi}=\frac{1-\tau_{1}^{d}}{1+\tau_{1}^{f}} \frac{1}{1+\mu_{1 t}} \frac{P_{1 t}}{P_{1 t}^{c}}(1-\alpha)^{2} \frac{Y_{1 t}}{N_{1 t} h_{1 t}} \\
w_{1 t} h_{1 t}=\frac{1-\epsilon_{1}}{1+\tau_{1}^{f}}\left[\omega_{1} \theta_{1 t}+\frac{1}{1+\mu_{1 t}} \frac{P_{1 t}}{P_{1 t}^{c}}(1-\alpha) \frac{Y_{1 t}}{N_{1 t}}\right]+\frac{\epsilon_{1}}{1-\tau_{1}^{d}}\left[b_{1 t}-\frac{\kappa_{1}^{n}}{\Lambda_{1 t}} \frac{\left(1-h_{1 t}\right)^{1-\xi}}{1-\xi}\right]
\end{gathered}
$$

\footnotetext{
${ }^{6}$ Christoffel, Küster, and Linzert (2006) or Poilly and Sahuc (2008) disentangle decisions related to price and quantities on one side, and vacancies opening and investment on the other, by introducing an intermediate sector and a final-good consumption sector. The model may be adapted in that direction as well. However, this would result in an increased complexity in the model's exposure, without modifying the key equations.
} 
with $\theta_{i t} \equiv \frac{V_{i t}}{U_{i t}}$ the labor market tightness in country $i=1,2$. As reported in equation (22), hours are bargained so that marginal return of worked hours (right member) equates the worker's marginal disutility of labor expressed in terms of real wealth (left member). In the monopolistic setting, the marginal return on hours departs from their marginal productivity, since the monopoly power of firms enable them extract positive rents.

Equation (23) reports that the representative worker's wage bill is a weighted average of i) the worker's contribution to output, plus hiring costs per unemployed workers (first term of the right-hand side of (23)), and ii) the worker's outside options, that are related to the gap between unemployed and employed workers expressed in terms of real wealth (second term of the right-hand side of (23)). As underlined by Christoffel and Linzert (2005), under efficient Nash-bargaining, any change in wage is accompanied by a change in hours, so that the "true" measure of firms' marginal labor cost is not the real wage, but the household's marginal rate of substitution of consumption and leisure (equation (22)). Besides, as shown by $\mu_{1 t}$ in equation (23), the monopolistic power of firms allows them to drive the real wage down in the Nashbargaining, since the marginal return of employment is lower than the true employment marginal productivity. Monopolistic competition adds a second source of distortion to the one induced by labor market frictions.

\subsubsection{The Government-central bank}

In each country, the monetary aggregate evolves as:

$$
M_{i t+1}=g_{i t} M_{i t}
$$

The monetary growth rates $\left\{g_{1 t}, g_{2 t}\right\}$ are modeled as a joint autoregressive stochastic process according to:

$$
\begin{aligned}
& \log g_{1 t+1}=\rho_{g} \log g_{1 t}+\rho_{g 12} \log g_{2 t}+\left(1-\rho_{g}-\rho_{g 12}\right) \log \bar{g}+\varepsilon_{1, t+1}^{g}+\psi_{g} \varepsilon_{2 t+1}^{g} \\
& \log g_{2 t+1}=\rho_{g} \log g_{2 t}+\rho_{g 12} \log g_{1 t}+\left(1-\rho_{g}-\rho_{g 12}\right) \log \bar{g}+\varepsilon_{2, t+1}^{g}+\psi_{g} \varepsilon_{1 t+1}^{g}
\end{aligned}
$$

where $\log \bar{g}$ is the mean of the process and $\left\{\varepsilon_{i}^{g}\right\}_{t}$ is the vector of monetary innovations serially independent and correlated between countries.

Stemming from the work by Taylor (1993), debates have been emerging on the most appropriate way to model monetary policy, notably in favor of interest rate rules. As indicated by equations (25) and (26), we rather retain a money supply rule. Since money supply is thus completely exogenous, this assumption allows to insulate the effects of "pure" money shocks in the world economy, and to focus on the role of divergent labor market institutions on that topic. Modeling interest rate rules in the model is left for further research.

Every period, the government has a balanced budget. The increase in the money supply and taxes are transferred to the local household. Transfers $T_{i t}$ endogenously adjust so as to balance 
country $i$ government's budget constraint:

$$
M_{i t+1}-M_{i t}+\tau_{i}^{c} P_{i t}^{c} C_{i t}^{c}+\left(\tau_{i}^{d}+\tau_{i}^{d}\right) N_{i t} w_{i t} h_{i t} P_{i t}^{c}=T_{i t}+\left(1-N_{i t}\right) b_{i t}
$$

\subsubsection{Equilibrium}

Absent any idiosyncratic shock, equilibrium is symmetric within a country and all firms set the same price $\left(p_{1 t}(z)=p_{1 t}(l)=P_{1 t}, p_{2 t}^{*}(z)=p_{2 t}^{*}(l)=P_{2 t}^{*}\right)$. The expressions of the consumption price index in each country (equation (36) and its foreign counterpart) become:

$$
\begin{aligned}
& P_{1 t}^{c}=\left[\kappa\left(P_{1 t}\right)^{1-\zeta}+(1-\kappa)\left[e_{t} P_{2 t}^{*}\right]^{1-\zeta}\right]^{\frac{1}{1-\zeta}} \\
& P_{2 t}^{c}=\left[\kappa\left(P_{2 t}^{*}\right)^{1-\zeta}+(1-\kappa)\left[\frac{P_{1 t}}{e_{t}}\right]^{1-\zeta}\right]^{\frac{1}{1-\zeta}}
\end{aligned}
$$

The model is closed by taking into account the equilibrium conditions on the following markets:

- Financial markets:

$$
B_{1 t+1}+B_{2 t+1}=0
$$

- The composite good market:

$$
D_{1 t}^{c}+\Gamma_{t} D_{2 t}^{c}=\frac{P_{1 t}}{P_{1 t}^{c}} Y_{1 t}+\frac{P_{2 t}^{*}}{P_{2 t}^{c}} \Gamma_{t} Y_{2 t}
$$

with $\Gamma_{t} \equiv \frac{e_{t} P_{2 t}^{c}}{P_{1 t}^{c}}$ the real exchange rate. Finally, taking into account the different market equilibrium conditions in the household's budget constraint, we obtain the law of motion of financial assets in the home country, that is the evolution of its balance of payments:

$$
B_{1 t+1}-\left(1+i_{t}\right) B_{1 t}=P_{1 t} Y_{1 t}-P_{1 t}^{c} D_{1 t}^{c}
$$

After having transformed the relevant equations so that they become stationary ${ }^{7}$, the long-run equilibrium is determined. Equations are then log-linearized around the steady state according to Farmer's (1993) methodology.

\section{Capturing divergence in labor market performances}

This section details the calibration of structural parameters, made on a quarterly basis. We focus on the role of cross-country divergence in the labor market functioning. We then introduce some asymmetry in the calibration of the related structural parameters, as reported in Table 3.

The calibration strategy relies on the following arbitrage. On the one hand, the empirical labor market literature (Blanchard and Wolfers (2000), Belot and Van Ours (2004)) points

\footnotetext{
${ }^{7}$ As we assume a positive money growth rate $g$, nominal variables are subject to long-run inflation. The first step then consists in transforming such variables, so that they become stationary.
} 
out that interactions in the various labour market institutions play a key role in employment performances. Fonseca, Patureau, and Sopraseuth (2007) obtain a similar result in terms of business-cycle comovement. This entices us to capture the various dimensions of heterogeneity among OECD labor markets, which calls for calibrating all related parameters asymmetrically across countries. On the other hand, we are faced to a requirement of parsimony, primarily due to calibration motives. Notably given our aim at confronting the model's predictions to the data in quantitative terms, calibration requires to be based on reliable values. For some LMI parameters (such as tax rates), we are able to calibrate values that differ across countries, while being empirically consistent. We cannot necessarily do so for some others (such as the matching technology parameters). In that case, we suppose the same calibration for both countries, based on values usually retained in the literature.

As a result, and as far as empirical estimates are available in the literature, values for country 1 are set so as to mimic the United States, i.e. the "flexible economy", while values for country 2 attempt to mimic the French economy, qualified as the "rigid" one. Our choice of calibrating on France and the United-States is consistent with information provided by the labor market institutions dataset for the sample of 15 OECD countries used in Section 2. We check that LMI values for France are higher than the median value of the country sample (i.e. that France features relatively more rigid labor market institutions), while those for the United-States are lower.

Table 3: Calibration of LMI parameters

\begin{tabular}{lc|cc}
\hline \hline & & Country 1 & Country 2 \\
& & Flexible & Rigid \\
\hline Job destruction rate & $s$ & 0.04 & 0.02 \\
Unemployment benefit ratio & $\frac{b}{w h}$ & 0.127 & 0.342 \\
Employment rate & $N$ & 0.93 & 0.9 \\
Employer's social contribution (in \%) & $\tau^{f}$ & 6.5 & 28.6 \\
Employee's social contribution (in \%) & $\tau^{d}$ & 15.5 & 12.3 \\
Indirect tax rate (in \%) & $\tau^{c}$ & 11.1 & 22.5 \\
\hline Weight of $V$ in the matching function & $\psi$ & \multicolumn{2}{|c}{0.6} \\
Weight of the firm in the match & $\epsilon$ & \multicolumn{2}{|c}{0.6} \\
Probability of matching a vacant job & $q$ & \multicolumn{3}{|c}{0.7} \\
\hline \hline
\end{tabular}

Asymmetries in labor market regulations are introduced though the following dimensions (top panel of Table 3).

- Labor-market heterogeneity is captured through cross-country divergence in tax rates. $\left(\tau_{i}^{f}, \tau_{i}^{d}, \tau_{i}^{c}\right)$ are set to the corresponding tax rate average values in France and the United States over 1982-1998, based on data provided by Nickell (2006). ${ }^{8}$ For $\tau_{i}^{c}$, we use the "in-

\footnotetext{
${ }^{8}$ Calibration related to LMI parameters is based on data averaged over 1982-1998. The sample starts in 1982
} 
direct tax rate" series, for $\tau_{i}^{d}$ the "direct tax rate" series and for $\tau_{i}^{f}$ the "Employment tax rate" (as denoted by Nickell).

- We capture difference in the generosity of the unemployment insurance system between the USA and France through the calibration of $b_{i}$ (assumed to be exogenous and constant). Using data provided by Nickell (2006), we calibrate the steady-state ratio $\frac{b}{w h}$ on the ratio defined as the average across the first five years of unemployment for three family situations and two money levels, in France and in the United-States. ${ }^{9}$

- Cross-country heterogeneity in the labor market functioning is captured by the steadystate value of unemployment. The value for $U$ is set so as to reproduce the standardized unemployment rate in the US and in France, based on data provided by the OECD over the period 1982-1998. Accordingly, we set $N_{1}=0.93$ and $N_{2}=0.9$.

- One major difference between the US and the French labor markets is tied to the mean duration of unemployment. From equation (3), it comes that, in steady state:

$$
s N=\phi(1-N)
$$

with $\phi$ the probability of finding a job for a worker. This probability is inversely related to the average duration of unemployment. Accordingly, using series of the duration of unemployment (in months) for France and the USA (for all men and women) ${ }^{10}$ over the period 1982-1998, we infer the probability of finding a job within the month. Translated into a quarterly value, we get that the probability of finding a job within the quarter is equal to 0.57 in the USA, and 0.22 in France. Given the calibration for $N_{i}$, this leads to a value for the job destruction rate equal to $s_{1}=0.043$ and $s_{2}=0.02$. One may interpret the lower job destruction rate (and, more largely, the lower magnitude of job flows) in country 2 , as resulting of more stringent employment protection laws. This view is consistent with a large bulk of empirical papers in the labor market literature showing that stringent EPL reduce job destruction (as well as job creation), as documented by Cahuc and Zylberberg (2004). A similar interpretation is made in Christoffel and Linzert (2005).

The other LMI parameters are set identical across countries, and equal to values commonly used in the labor market RBC literature (bottom panel of Table 3). As in Campolmi and Faia (2006) or Chéron and Langot (2004), we set the weight of vacant jobs $V$ in the matching function

because of data availability constraints, namely regarding the mean duration of unemployment used to get $\phi$ and $s$, as detailed further.

${ }^{9}$ Nickell's database provides other benefit replacement ratios, such as " $b r r_{1}$ " that refers to the first year of unemployment benefits, averaged over three family situations and two earnings levels. Calibrating on this ratio would imply higher values than those considered here. However, results would not be substantially modified since the cross-country difference remains of same magnitude.

${ }^{10}$ Calibration is not much altered when considering only men. 
to $\psi=0.6$. We preserve the Hosios (1990) condition by setting the bargaining power of firms in the Nash-bargaining $\epsilon=0.6$ as well. As a result, wage and hours bargaining is such that trade externalities on the labor market do not distort equilibrium. However, distortions due to the monopolistic competition setting still remain. The probability that a vacant job is matched is set to 0.7, as in Den Haan and Watson (2000) and Kraus and Lubik (forthcoming).

Calibration of the other parameters unrelated to the labor market, is presented in Tables 4 and 5. The parameter $\alpha$ corresponds to the elasticity of output with respect to capital, estimated to 0.36 by Kydland and Prescott (1982) on US data. The discount factor $\beta$ is set to 0.99, which corresponds to a real annual interest rate is equal to $4 \%$, as in Campolmi and Faia (2006) or others. The depreciation rate of capital is about $10 \%$ a year, implying $\delta=0.025$ on a quarterly basis. $(1-\kappa)$ represents the steady-state value of imports to GDP. Kollmann (2001) suggests a value equal to 0.1 in the United States, while Campolmi and Faia (2006) set a value of 0.4 for European countries. We set an intermediate value, equal to 0.25 in both countries. The steadystate gross inflation value of $\bar{\pi}$ is set to 1 . Following Basu and Fernald (1997), we set the mark-up rate of price over marginal cost to 0.2 . This gives a value for the price elasticity of demand $\eta$ equal to 6 . For the G7 countries, a vast consensus estimates the elasticity between national varieties $\zeta$ between 0 and 1.5 (see Hooper and Marquez (1995)). We follow the literature (Corsetti and Pesenti (2001) among others) by setting $\zeta=1$. Calibration of $\xi$ is based on estimated of the labor-supply elasticity $\epsilon_{h}$, given the steady-state relation $\xi=\frac{1-h}{h} \epsilon_{h}$. The literature does not reach some clear-cut consensus regarding the value of $\epsilon_{h}$. As in Chéron and Langot (2004) and Hairault (2002), we choose $\xi=4$ so that the average individual labor supply elasticity is equal to 0.5, consistently with the bulk of empirical micro-estimates (MaCurdy (1981)). As standard in the labor market literature, the steady-sate value for hours is set to $h=1 / 3$ (Chéron and Langot (2004)). Based on the empirical results of Lane and Milesi-Ferretti (2001) on major developed countries, and as in Kollmann (2004), $\Phi_{b}$ is calibrated so that $\Phi_{b} / N X=0.0038$, with $N X$ the steady-state value of exports. The capital adjustment costs parameter $\Phi_{I}$ is taken from Patureau (2007), and close to Kollmann (2001), which calibrate the value in order to match the relative volatility of investment in the G7 countries. Last, adjustments costs on prices $\Phi_{P}$ are set to 50 . In a Calvo-type framework ${ }^{11}$, this implies an average duration of the price contract of one year, a value frequently retained in the literature (Kollmann (2001) among others). Table 4 sums up the previous calibrated values.

Table 4: Calibration of structural parameters

\begin{tabular}{cccccccccccc}
\hline \hline$\alpha$ & $\beta$ & $\delta$ & $\kappa$ & $\bar{\pi}$ & $\eta$ & $\theta$ & $\xi$ & $h$ & $\Phi_{I}$ & $\Phi_{P}$ & $\frac{\Phi_{b}}{N X}$ \\
\hline 0.36 & 0.988 & 0.025 & 0.75 & 1 & 6 & 1 & 4 & 0.33 & 7 & 50 & 0.0038 \\
\hline \hline
\end{tabular}

\footnotetext{
${ }^{11}$ See Keen and Wang (2007) for the mapping between quadratic adjustments costs on prices and Calvo's (1983) type of price stickiness.
} 
Table 5 reports the calibration of stochastic processes in the model. The technological process parameters are taken from Backus, Kehoe, and Kydland (1995), with the steady-state technology level $A$ set to 1 . The calibration of the monetary process is based on Kollmann (2001), which estimates the joint process followed by the monetary aggregates of the United States and its G7 partners between 1973 and 1994. Using this calibration will allow us to compare our results with other studies in the literature using the same variability and persistence in aggregate shocks. The steady-state value of $g$ is imposed by our calibration of $\bar{\pi}$.

Table 5: Calibration of stochastic processes

\begin{tabular}{ccccc|ccccc}
\hline \hline \multicolumn{4}{c|}{ Technological process } & \multicolumn{5}{c}{ Monetary process } \\
\hline $\bar{A}$ & $\rho_{a}$ & $\rho_{a 12}$ & $\sigma_{\varepsilon a}$ & $\psi_{a 12}$ & $\bar{g}$ & $\rho_{g}$ & $\rho_{g 12}$ & $\sigma_{\varepsilon g}$ & $\psi_{g 12}$ \\
1 & 0.906 & 0.088 & 0.00852 & 0.13 & 1 & 0.3 & 0 & 0.009 & 0.1 \\
\hline \hline
\end{tabular}

\section{Divergence in LMI and IRF analysis}

The section investigates the role of labor market heterogeneity on the dynamic behavior of macroeconomic variables in response to exogenous shocks. As in Campolmi and Faia (2006), we start from the benchmark case where countries are perfectly symmetric, and featured with flexible labor market regulations. Structural parameters in both countries are calibrated according to the "Country 1" values reported in Table 3, corresponding to the US labor market. Two types of shocks may be contemplated, supply shocks (global productivity of factors) and demand shocks (monetary shocks). In each case, we proceed in two steps. We first analyze impulse response functions (IRFs) analysis in the benchmark symmetric case. We then introduce labor market heterogeneity to analyze how it affects IRFs of macroeconomic variables to aggregate shocks.

\subsection{Dynamics following a technological shock}

In the symmetric case Figure 1 reports the IRFs of aggregate consumption, investment, and output in both countries, and of the real exchange rate following a $1 \%$ increase in the home technological level $A_{1}$ in period 1. Figure 2 reports the IRFs of the negotiated wage and hours, of job vacancies and of the employment level in both countries. ${ }^{12}$

The increase in the global factors productivity entices domestic agents to invest in physical capital. The positive wealth effect induced by the supply shock accounts for the rise in home consumption (Figure 1, $\widehat{I}_{1}^{c}>0$ and $\widehat{C}_{1}^{c}>0$ ). As well, the household arbitrages more in favor of leisure, which leads to a subsequent decrease in the negotiated amount of worked hours in the period of the shock (Figure 2). Besides, the intertemporal smoothing behavior of domestic agents

\footnotetext{
${ }^{12}$ Throughout the section, exogenous shocks are assumed uncorrelated across countries, so as to highlight the internal propagation mechanisms of shocks at work. As compared to calibration reported in Table 5, we set $\rho_{a 12}=\psi_{a}=0$, and $\rho_{g 12}=\psi_{m}=0$.
} 
Figure 1: IRFs to a home supply shock, symmetric LMI (1)
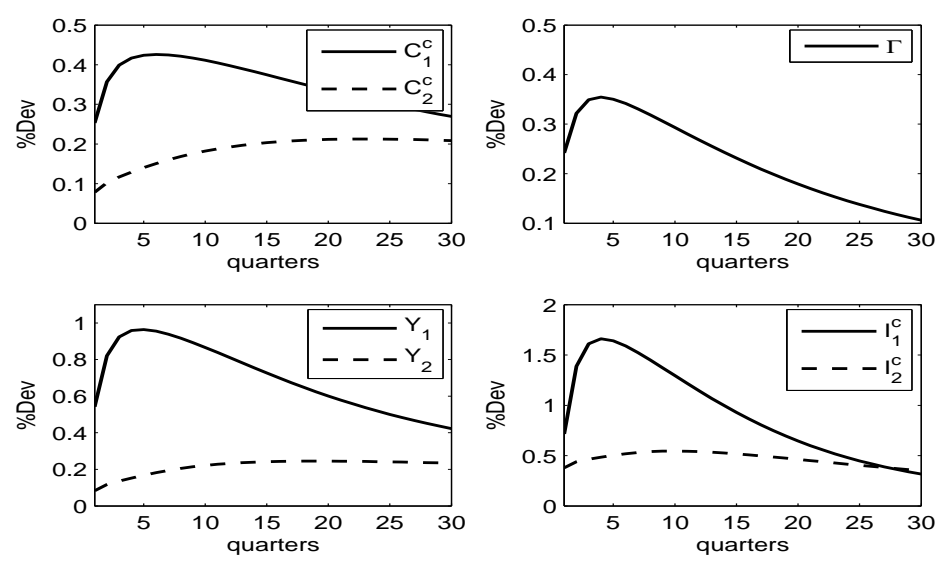

Figure 2: IRFs to a home supply shock, symmetric LMI (2)
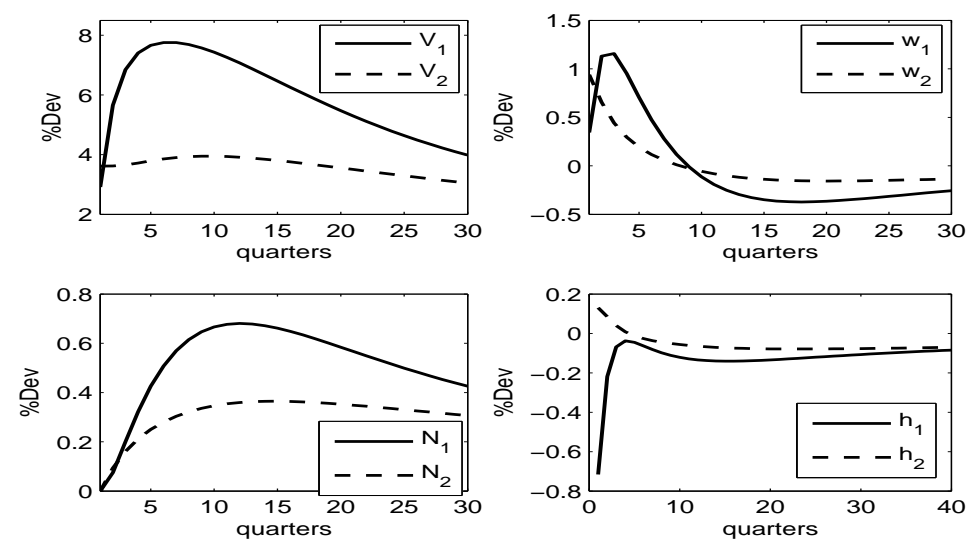

leads them to report part of the increase in wealth in future periods. They consequently invest in international financial assets, thereby allowing the foreign household to consume more than its production. As a result, both domestic and aggregate demands increase with the technological shock. In the monopolistic-competition setting where output is demand-determined, the so-called "expenditure-shifting" effect tends to increase both domestic and foreign outputs on impact.

This effect is partially counteracted by the "expenditure-switching" effect, that favors domestic goods at the expense of foreign ones. The productivity shock indeed reduces marginal costs of domestic firms, leading to a reduction in the relative price of domestic varieties and a real exchange rate depreciation (Figure 1). The expenditure-shifting effect dominates, as Figure 1 reports an increase in both $Y_{1}$ and $Y_{2}$ with the home supply shock. The immediate increase in foreign output requires an increase in worked hours, so as firms to be able to answer expansion world demand. Foreign workers accept to bargain a larger amount of worked hours, as it is accompanied by an increase in real wage (Figure 2). 
Figure 2 reports an increase in vacancies in both countries. Firms are indeed enticed to post more vacant jobs, so as to be able to produce more the second period on by an adjustment through extensive margin (employment) rather than intensive margin (hours). As underlined by Hairault (2002), due to the time-consuming nature of search, increase in employment is only progressive, resulting in a hump-shape response in both countries. This internal propagation mechanism induces positive comovement between employment across countries. The dynamics of employment interacts with that on capital investment, and accounts for the hump-shape response of output (Figure 1).

One can wonder how well do these IRFs correspond to the empirical facts. Corsetti, Dedola, and Leduc (2004) estimate a VAR on US data relative to the aggregate of other OECD countries. They find that, following a home technological improvement, US output and consumption relative to foreign increase. This is consistent with our findings. The effects of supply shocks on employment are far less consensual. Chang and Hong (2005), using total factor productivity (TFP) as a measure of productivity shocks, obtain an increase in worked hours with a positive supply shock in US data. On the contrary, using labor productivity rather than TFP, Gali (1999) or Basu, Fernald, and Kimball (2006) find a negative impact on total worked hours in the short-run. We obtain results consistent with theirs on impact.

These results shed light on the importance of modeling both labor market and good market frictions. As noted by Andolfatto (1996), the hump-shape employment response that results from labor-market frictions is a key ingredient to match the positive autocorrelation of output growth rate. Besides, monopolistic competition and nominal rigidities play a key role in output responses. The model with labor market frictions only would indeed predict a negative response of foreign output with the home supply shock, stemming from the reduction in foreign worked hours due to the wealth effect in labor supply decisions. This would result in a negative cross-country GDP correlation, thereby reducing the model's ability to account for international comovement. ${ }^{13}$ This is no more the case in the demand-determined monopolistic setting with price rigidities. In line with Kollmann's (2001) results, this element is key for the model to predict a positive comovement of outputs following the supply shock.

The role of cross-country divergence in labor market institutions We now focus on the case when countries are asymmetric in their labor market functioning. Precisely, we analyze how labor market heterogeneity induces countries to react differently to the same aggregate supply shock. This analysis is close in spirit with the empirical study performed by Blanchard and Wolfers (2000), when they investigate the role of interaction between heterogeneous labor market institutions and common aggregate shocks on labor market performances across OECD countries.

\footnotetext{
${ }^{13}$ Hairault (2002) needs to introduce specific preferences à la Devereux, Gregory, and Smith (1992) that cut off wealth effects in labor supply to overcome this limit of the two-country matching model.
} 
Country 1 remains "flexible", while country 2 is now "rigid", according to calibration displayed in Table 3. Figure 3 displays the IRF of the GDP differential $\widehat{Y}_{1}-\widehat{Y}_{2}$ to a $1 \%$ increase in both $A_{1}$ and $A_{2}$ in period 1 (in deviation from steady-state), as well as the IRF of output in the symmetric case (indifferently $\widehat{Y}_{1}$ or $\widehat{Y}_{2}$ ), and in each country in the asymmetric case. In the benchmark symmetric case, there is no GDP differential in response to a common supply shock. Figure 4 reports the response of worked hours, of vacancies, of wages and of employment in both countries in the case of heterogenous labor market institutions.

Figure 3: Common supply shock and GDP differential
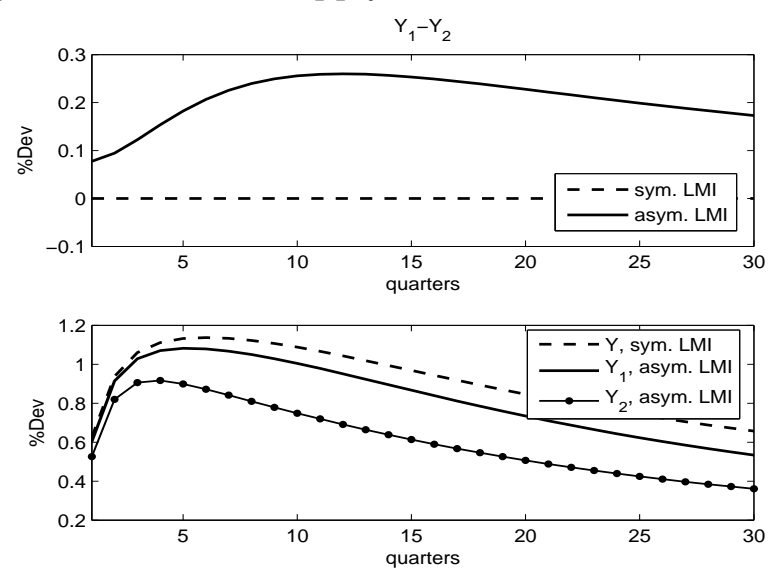

Figure 4: Common supply shock and asymmetric LMI
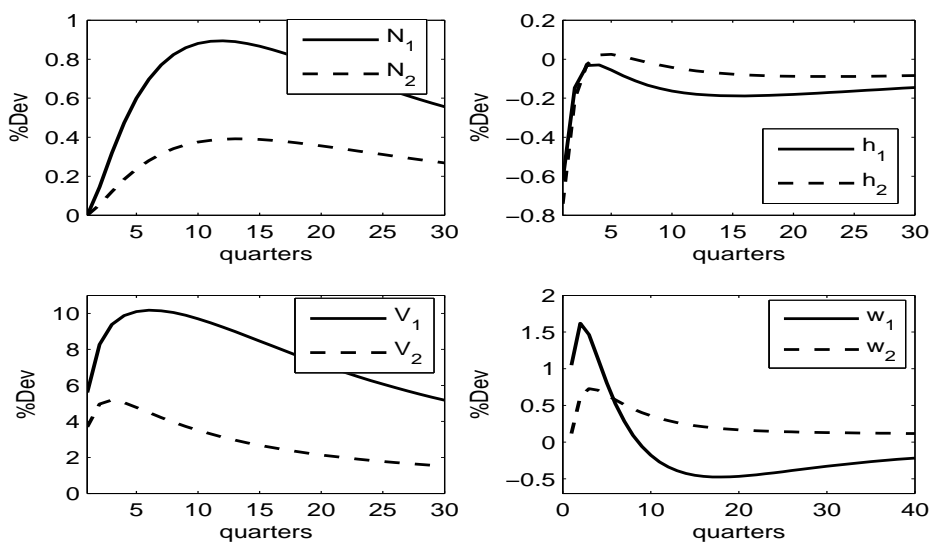

As reported in Figure 3 (top panel), divergence in the labor market institutions generates a substantial cyclical GDP differential in response to the common supply shock. Figure 3, bottom panel, reports that domestic GDP increases more than abroad, both on impact and after the shock. Asymmetric labor market institutions are thus responsible for a persistent GDP differential, in favor of the flexible economy. Besides, expansion is more limited in both countries, as compared to the benchmark symmetric case (Figure 3, bottom panel). 
The underlying rationale may be explained, by referring to IRFs reported in Figure 4. Both countries benefit from the same positive global productivity shock. Given the predetermined levels of employment and capital stocks, the more limited increase in foreign output on impact comes from the larger reduction in worked hours, as shown in Figure 4. In both countries, the positive wealth effect in labor supply decisions leads to a reduction in negotiated worked hours. The larger decrease in worked hours in the foreign country (relative to home) is tied to the more limited increase in the negotiated wage (Figure $\left.4, \widehat{w}_{1}>\widehat{w}_{2}\right)$. This can be explained recalling the solution of the Nash bargaining that drives the dynamics of $w$ (equation (23), in country 1):

$$
w_{1 t}=\frac{1-\epsilon}{1+\tau_{1}^{f}}\left[\frac{1}{1+\mu_{1 t}} \frac{P_{1 t}}{P_{1 t}^{c}}(1-\alpha) \frac{Y_{1 t}}{h_{1 t} N_{1 t}}+\omega_{1} \theta_{1 t}\right]+\frac{\epsilon}{1-\tau_{1}^{d}}\left[\frac{b_{1 t}}{h_{1 t}}-\frac{\kappa_{1}^{n}}{h_{1 t} \Lambda_{1 t}} \frac{\left(1-h_{1 t}\right)^{1-\xi}}{1-\xi}\right]
$$

Every thing else equal, the increase in labor productivity exerts an upward pressure on the real wage, even though the effect is dampened by the increase in the mark-up rate monopolistic firms extract (first term into bracket). The dynamics of the real wage is also driven by that of the outside options of the workers (second term into brackets). Given the poorer structural labor market performances in country 2 , the effective bargaining power of workers to negotiate high wages in the occur of a positive supply shock, is more limited than in the flexible country 1 . As a result, the real wage increases more in the home flexible country, relative to the foreign one, both instantaneously and for some periods after the shock. ${ }^{14}$

The positive common shock generates an increase in consumption and investment in both countries, i.e. an increase in world demand for goods, leading to a positive comovement in output across countries. ${ }^{15}$ In both countries, firms are enticed to post vacant jobs, so as to adjust through extensive margin. As in the benchmark symmetric case, this implies a humpshape response in employment (Figure 4), hence in output (Figure 3). However, the magnitude of the increase both in vacancies and employment is much more limited in country 2 , where firms are less enticed to post vacant jobs in the more sclerotic labor market. Consequently, adjustment in country 2 occurs relatively more through the intensive margin, as compared to the flexible economy. Given the more limited increase in employment, foreign firms have to agree upon high wages to avoid a too strong reduction in worked hours, that would prevent them from increasing production enough. The periods after the supply shock, this results in a more limited increase in employment and output in the foreign economy featured with rigid labor market institutions.

\footnotetext{
${ }^{14}$ Given the calibration of the unemployment benefit ratios $b / w h$, one might have expected the opposite result, with $\widehat{w}_{2}>\widehat{w}_{1}$. Ceteris paribus, it is indeed the case that the more generous unemployment benefit ratio in country 2 tends to increase outside options, hence the real wage relatively more in the rigid foreign economy. However, the wage equilibrium value results from the whole set of labor market institutions in place. One notable implication of the asymmetric calibration is that steady-state values differ across countries. In particular, the steady-state values of $V, \chi$, labor market tightness $\theta$ and of the real wage $w$ are lower in the foreign country, featured with more rigid LMI. This matters in the dynamic behavior of the model since the steady-state values enter the equation system in its log-linearized version.

${ }^{15}$ However, there is still an expenditure-switching effect, coming from the real exchange rate depreciation, in favor of domestic firms. IRFs of consumption, investment and the real exchange rate are not reported here for sake of space saving, but they are available to the authors upon request.
} 
Accordingly, the cross-country GDP differential remains persistently positive, in favor of the flexible economy.

\subsection{Dynamics following a demand shock}

As for supply shocks, we start analyzing IRFs to a positive monetary shock in the symmetric case (both countries being flexible). We consider the dynamic effects of a $1 \%$ increase in the monetary growth factor in the domestic country. We then turn to the case where labor market institutions differ across countries.

In the symmetric case Figure 5 reports the IRFs of aggregate consumption, investment, and output in both countries, and of the real exchange rate following a $1 \%$ increase in the home monetary growth factor $g_{1}$ in period 1. Figure 6 reports the IRFs of the negotiated wage and hours, job vacancies and employment level in both countries.

Figure 5: IRFs to a positive home money, symmetric LMI (1)
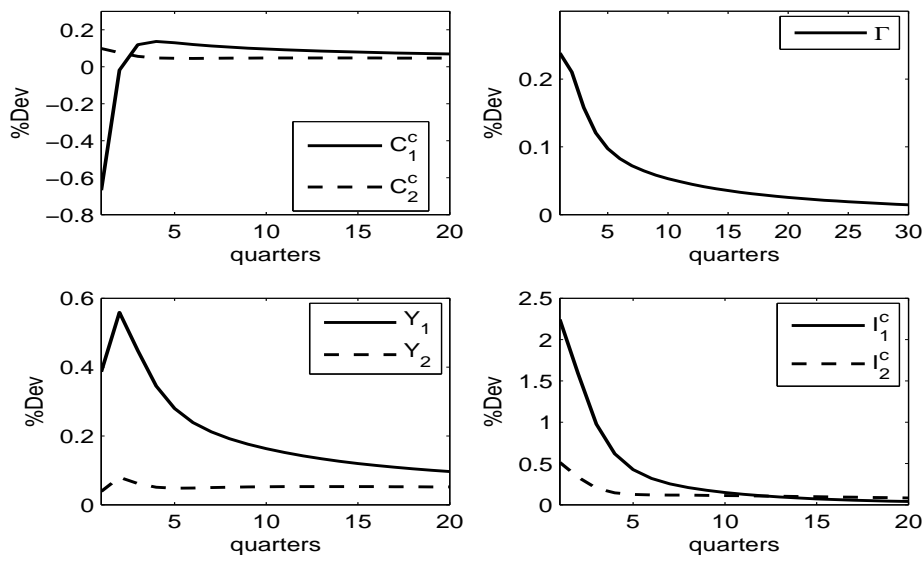

Figure 6: IRFs to a positive home money shock, symmetric LMI (2)
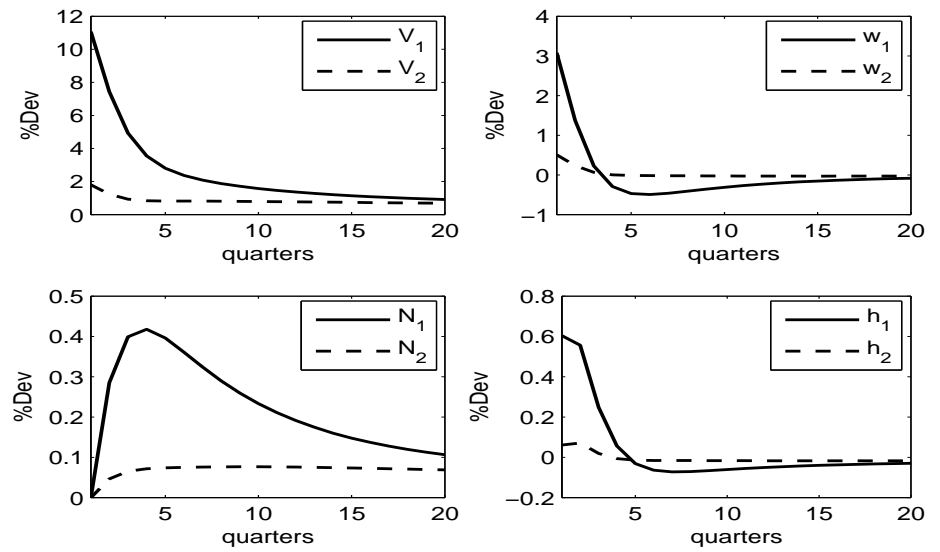
The rationale underlying these IRFs is the following. In the home country, the monetary injection drives inflation up, which negatively affects domestic consumption given the cash-inadvance constraint. The household escapes the inflationary tax by favoring leisure and investment in physical capital (Figure 5, $\widehat{I}_{1}^{c}>0$ and $\widehat{C}_{1}^{c}<0$ ). Despite the reduction in consumption, home aggregate demand increases with the monetary injection. Besides, the intertemporal smoothing behavior of the household entices her to invest in financial assets as well. Through the external account dynamics, this induces a positive international transmission of the home monetary shock. As shown in Figure 5, foreign consumption and investment increase, and demand for goods raises at the world-wide level. The expenditure-shifting effect exerts an upward pressure on production in both countries. However, foreign firms suffer from the expenditure-shifting effect, coming from the real exchange rate depreciation. The rise in domestic inflation indeed generates a depreciation of the home currency, which translates into a real exchange rate depreciation due to nominal price rigidity. The rise in output is consequently larger in the home country than abroad, as shown in Figure 5.

On impact, both domestic and foreign firms have a strong incentive to negotiate an increase in worked hours, since it is the only way to raise production. Conversely, workers have a strong incentive to bargain a reduction in worked hours, as their outside options increase with the wealth effect. This is particularly the case in country 1 , where consumption is hit by the inflationary tax. As displayed in Figure 6, the Nash-bargaining process results in an increase in worked hours, accompanied by an increase in wage, and particularly in the home country.

The second period on, as soon as employment and capital stocks can be adjusted to production, firms are less willing to accept high wages when negotiating the labor contract, to rather adjust through stocks. This accounts for the decrease in real wage and in worked hours the second period on in Figure 6. This comes at the benefit of an increase in stocks, as shown by the significant raise in capital (given the investment boom on impact, Figure 5) and employment, consecutive to the opening of new vacancies the period of the shock (Figure 6). The progressive upward adjustment in employment explains the hump-shape response of employment (in both countries) displayed in Figure 6. The interaction between employment dynamics and the capital investment dynamics is key to account for the hump-shape response of GDP to the monetary shock, in both countries.

How well do these IRFs fit the data? As underlined by Christiano, Eichenbaum, and Evans (1999), despite the various techniques of identifying money shocks, there is a reasonable consensus on the following effects. Christiano, Eichenbaum, and Evans (1999) survey that after a positive monetary shock, output ultimately rises, exhibiting a hum-shape response. Consumption and investment increase, the latter being more responsive to the initial shock, and employment increase after a delay. Inflation goes up and nominal and real exchange rate depreciates. Kashyap and Mojon (2003) obtain similar VAR results on European countries. The model's predictions are broadly consistent with these empirical results. Nevertheless, two limits may be underlined. 
First, consumption contracts with a positive money shock, while it increases in the data. This is a well-known limit of the models that introduce money through a cash-in-advance constraint, as shown by Christiano (1991) in a closed-economy setting. Second, and despite nominal price rigidity, the magnitude of the real exchange rate depreciation $(0.25 \%$ depreciation on impact, versus $0.6 \%$ maximum increase in GDP, Figure 5) seems too low to be able to account for the relative volatility of the real exchange rate observed in the data.

Despite these shortcomings, one can conclude that the model is consistent with major stylized facts of a money shock identified in the empirical literature. Having modeled both labor-market and goods-market frictions plays a key role in that result. Unlike Kollmann (2001), labor-market search makes the monopolistic competition model able to replicate the hump-shape response of GDP and employment to the money shock. Besides, due to real and nominal rigidity on the goods market, the model predicts a positive response of outputs in both countries to the home demand shock, consistently with the data (Schlagenhauf and Wrase (1995) notably).

The role of cross-country divergence in labor market institutions We now focus on the way divergence in labor market institutions affects the dynamic behavior of the two countries in response to the same positive monetary shock. Country 1 remains "flexible", while country 2 is now "rigid", according to calibration displayed in Table 3. Figure 7 displays the IRF of the GDP differential $\widehat{Y}_{1}-\widehat{Y}_{2}$ to a $1 \%$ increase in both $g_{1}$ and $g_{2}$ in period 1 (in deviation from steady-state), as well as the IRF of output in the symmetric case (indifferently $\widehat{Y}_{1}$ or $\widehat{Y}_{2}$ ), and in each country in the asymmetric case. Figure 8 reports the response of worked hours, of vacancies, of wages and of employment in both countries, in presence of labor market heterogeneity.

Figure 7: Common money shock and asymmetric LMI (1)
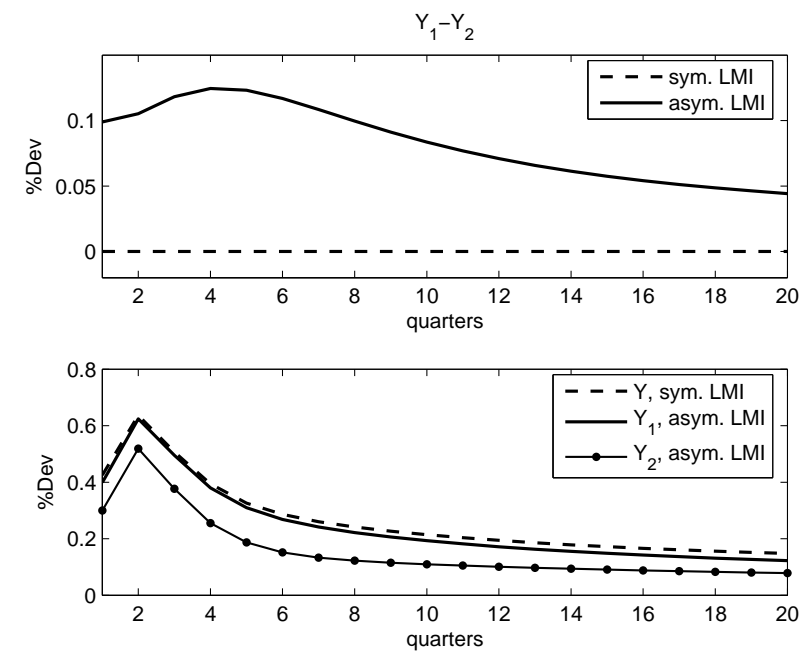

Figure 7, top panel, displays that the GDP differential $\widehat{Y}_{1}-\widehat{Y}_{2}$ is positive: the flexible economy 
Figure 8: Common money shock and asymmetric LMI (2)
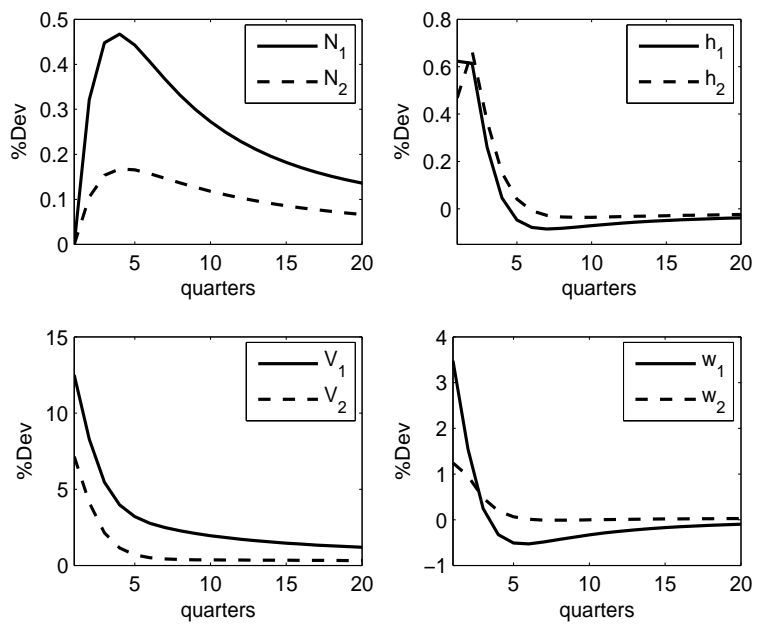

benefits more from the common demand shock (in terms of output) than the foreign economy, characterized by more stringent LMI. Besides, expansion in both countries is more limited as compared to the symmetric case (Figure 7, bottom panel). Cross-country GDP differential mostly comes from a more dampened increase in foreign output, as the response of $Y_{1}$ is only slightly altered by the design of labor market institutions abroad.

On impact, the positive world-wide demand shock drives the negotiated values of wage and worked hours up, so as firms to adjust production in the demand-determined monopolistic framework (Figure 8). Increases in wage and worked hours are more pronounced at home than abroad. Similarly as in the case of supply shocks, the poorer performances of the foreign labor market limit the ability of foreign workers to negotiate high wages, which goes with a limited increase in negotiated worked hours in the Nash-bargaining process. As a result, worked hours raise by more in the home country (Figure 8), which explains the instantaneous positive GDP differential (Figure 7).

More stringent labor market institutions limit the incentive for foreign firms to adjust through extensive margin by opening vacant jobs, as compared to domestic firms (Figure 8, $\widehat{V}_{1}>\widehat{V}_{2}$ ). The second period on, the increase in the employment level is much stronger in the home country than abroad, as shown in Figure 8. As a result, more stringent LMI limit the ability of the foreign country to raise employment and output in response to the world-wide demand shock, both on impact and persistently after the shock. Asymmetric labor market institutions thus generate a cyclical persistent GDP differential, in favor of the more flexible economy. 


\subsection{Conclusion of IRFs analysis}

Analysis of the IRFs to demand shocks and supply shocks may be summed up in three points. First, the benchmark symmetric case shows that good market frictions and labor market frictions complement each other in shaping IRFs of macroeconomic variables. Monopolistic competition and nominal price rigidity make the model able to predict a positive correlation of outputs with either technological or monetary shocks. Conversely, labor market search frictions play a key role in matching the hump-shape response of GDP to a money shock found in the data. These results yield the conclusion that both good and labor market frictions are needed to correctly account for international fluctuations.

Second, asymmetry in labor market institutions reduces international comovement, as it generates cyclical GDP differential in response to common shocks. Output differentials are mostly attributable to more limited responses of employment and output in the economy featured by more stringent LMI.

Third, the effects of divergent LMI on GDP differential are persistent. In both cases of supply and demand shocks, the instantaneous effects on GDP differential, coming from divergence in the amount of negotiated worked hours, are filled in by persistent differences in the dynamics of job flows the periods after the shock.

\section{Divergence in LMI and international business cycle comove- ment}

According to the stylized facts presented in Section 2, labor market heterogeneity significantly reduces cross-country GDP correlation in OECD countries. This section evaluates whether the model's quantitative predictions are in line with these findings. To that aim, we simulate the model subject to monetary shocks and/or to technological shocks. Similarly as in Section 5, we compare the quantitative performances of the model in the case when countries are perfectly symmetric (and adopt flexible labor market institutions), and when they differ with respect to their labor market functioning, country 2 featuring stringent labor market institutions. ${ }^{16}$

Table 6 reports quantitative results regarding cross-country correlations. Following Hairault (2002), we tackle the international comovement issue by focusing on cross-country correlation of output $\left(\rho\left(Y_{1}, Y_{2}\right)\right)$, total worked hours $\left(\rho\left(N h_{1}, N h_{2}\right)\right)$ and consumption $\left(\rho\left(C_{1}^{c}, C_{2}^{c}\right)\right)$. Table 6

\footnotetext{
${ }^{16}$ There is a vivid current debated in the labor market literature regarding the role of real wage stickiness, initiated by the papers of Hall (2003) and Shimer (2005). They argue that this mechanism substantially improves the ability of DSGE models to account for the correlation between unemployment and vacancies. Christoffel and Linzert (2005) show that it helps reproducing wage and inflation dynamics. This (unsolved) debate leads us to build a variant of the model with real wage rigidity. We find that real wage stickiness reduces volatility of the real wage, while increasing its persistence, as already noted by Christoffel and Linzert (2005) in a closed-economy setting. However, quantitative results related to the comovement issue are left unaffected by the real wage rigidity, once asymmetric LMI have been taking into account. For sake of space saving, we consequently to not report these results here. They are available upon request to the authors.
} 
reports these moments when the model is subject to demand shocks (column (A)), supply shocks (column (B)) and both types of shocks (column (C)). For each macroeconomic variable, line (1) reports the correlation obtained when LMI are symmetric, line (2) when they are asymmetric. Column (D) reports the same statistics observed in the data, taken from Backus, Kehoe, and Kydland (1995). These data correspond to the median value of the correlations observed with the same US variable of a sample of 10 OECD countries over the period 1970-mid 1990s. ${ }^{17}$

Besides, last lines $(a)$ and $(b)$ in Table 6 reports the standard-deviation (in \%) of output and employment in the foreign (rigid) country, relative to the home (flexible) one, in the case of asymmetric labor markets. We follow here the approach of Campolmi and Faia (2006), which assess the role of asymmetric labor markets institutions in generating volatility differentials (in inflation in their case). So as to gauge the empirical relevance of these results, we report the similar statistics observed in the data in column (D). It corresponds to the ratio of the median standard-deviation of output (line $(a)$ ) and employment (line $(b)$ ) of a sub-sample of countries whose LMI may be qualified as rigid ${ }^{18}$, relative to that of a sub-sample of countries whose LMI may be considered as flexible. ${ }^{19}$ The reasoning underlying the country sub-sample choice is detailed in Appendix A.

Table 6: Asymmetries in LMI and international comovement

\begin{tabular}{l|ccc|c}
\hline \hline & $\begin{array}{c}\text { Money shocks } \\
(\mathrm{A})\end{array}$ & $\begin{array}{c}\text { Tech. shocks } \\
(\mathrm{B})\end{array}$ & $\begin{array}{c}\text { Both shocks } \\
(\mathrm{C})\end{array}$ & $\begin{array}{c}\text { Data } \\
(\mathrm{D})\end{array}$ \\
\hline$\rho\left(Y_{1}, Y_{2}\right)$ & \multicolumn{5}{l}{} \\
\hline $\begin{array}{l}(1) \quad \text { Symmetric LMI } \\
(2) \quad \text { Asymmetric LMI }\end{array}$ & 0.562 & 0.808 & 0.762 & 0.51 \\
\hline$\rho\left(N h_{1}, N h_{2}\right)$ & 0.521 & 0.734 & 0.687 & \\
\hline$(1) \quad$ Symmetric LMI & 0.559 & 0.725 & 0.662 & 0.36 \\
$(2) \quad$ Asymmetric LMI & 0.516 & 0.593 & 0.561 & \\
\hline$\rho\left(C_{1}^{c}, C_{2}^{c}\right)$ & \multicolumn{5}{l}{} \\
\hline (1) Symmetric LMI & 0.207 & 0.875 & 0.509 & 0.40 \\
$(2) \quad$ Asymmetric LMI & 0.195 & 0.822 & 0.495 & \\
\hline Relative volatility & \multicolumn{5}{l}{} \\
\hline (a) $Y_{2} / Y_{1}$ & 0.80 & 0.82 & 0.82 & 0.79 \\
(b) $N h_{2} / N h_{1}$ & 0.77 & 0.89 & 0.84 & 0.67 \\
\hline \hline
\end{tabular}

Quantitative results are analyzed using a similar approach as in the IRFs analysis (Section 5). We first evaluate the broad business-cycles properties of the model, in the case of symmetric labor market institutions. In a second step, we focus on the role of labor market heterogeneity in affecting such properties.

\footnotetext{
${ }^{17}$ Note that Backus, Kehoe, and Kydland (1995) report the cross-country correlation of employment rather than that of total worked hours. Empirical evidence reported by Ambler, Cardia, and Zimmermann (2004) suggest that both are very close.

${ }^{18}$ i.e. Austria, France, Germany and Italy within the Backus, Kehoe, and Kydland (1995) 10-country sample.

${ }^{19}$ i.e. Canada, Switzerland, the United-Kingdom and the United-States.
} 
Evaluating the broad quantitative performances of the model We focus first on results obtained when countries are symmetric (Table 6, line (1)). The model predicts a lower crosscountry correlation of consumption than of output, consistently with the data (column (D)). The inability of the canonical international RBC model of Backus, Kehoe, and Kydland (1995) to account for this stylized fact lies at the origin of a large strand of papers that attempt to solve the so-called "consumption correlation puzzle". Baxter and Crucini (1995) underline the role of incomplete financial markets in reducing cross-country consumption correlation. ${ }^{20}$ Consistently with the related literature, including financial markets incompleteness contributes to make the model consistent with the lower international comovement in consumption than in output found in the data.

This result also relies on the ability of the model to predict a large cross-country GDP correlation. Conversely, international real business cycles models typically fail in front of the "quantity puzzle", i.e. they fail to capture the high degree of comovement among industrialized countries. The seminal two-country RBC model of Backus, Kehoe, and Kydland (1995) thus predicts a negative cross-country GDP correlation (0.51 in the data). Hairault (2002) and Kollmann (2001) make notable contributions on that topic. Hairault (2002) highlights the role of labor market frictions (combined to supply shocks) in enhancing GDP comovement. Kollmann (2001) stresses the importance of nominal price rigidities and monetary shocks on business cycle comovement as well. However, none of these models is able to generate enough international interdependence in GDP: the cross-country GDP correlation remains too low, as compared to the data. ${ }^{21}$ Based on these conclusions, we have introduced both types of frictions in the model. This substantially improves the results, since the model does not fail in front of the quantity puzzle. In line with the conclusion drawn from the IRFs analysis (Section 5), this shows that both types of market frictions are needed in order to account for international comovement.

Paradoxically however, the benchmark symmetric model predicts a magnitude of international comovement, which is even higher than observed. This calls for introducing a source of business cycle divergence in the model based on goods and labor market frictions. As shown in Section 5 , this may be achieved by taking into account heterogeneity in labor market institutions. We now investigate that point in quantitative terms.

The role of asymmetries in LMI Results reported in Table 6 show that divergence in labor market institutions does substantially reduce international interdependence. Cross-country GDP correlation is lower when LMI differ across countries (Table 6, line (2)). This is the case whether countries are subject to demand and/or supply shocks. This result is in line with the

\footnotetext{
${ }^{20}$ Other routes have been pursued in the literature on the consumption puzzle issue, notably the role of preferences (Devereux, Gregory, and Smith (1992)) or that on non-tradable goods (Stockman and Tesar (1995)).

${ }^{21}$ Hairault (2002) reports a cross-country GDP correlation equal to 0.29 (for standard preferences) while it amounts to 0.42 in Kollmann (2001). Besides, both models predict a cross-country correlation in GDP lower than in consumption.
} 
conclusion drawn from the IRFs analysis, that asymmetries in labor market institutions enlarge GDP differential across countries. Heterogeneous labor markets also reduce the cross-country correlation of total hours and of consumption. All cross-country correlations are now closer to those observed in the data, which suggests that heterogeneity in labor market institutions matters if willing to account for international comovement among OECD countries.

Divergence in labor market institutions also affects international comovement as captured by relative performances in volatility. As reported in lines $(a)$ and $(b)$ of Table 6 , volatility in output and employment is lower in the country featured with more stringent labor market institutions (i.e., country 2). This result is consistent with the IRFs analysis made in Section 5. More stringent LMI reduce job flows, hence the magnitude of the responses of foreign employment and output to aggregate shocks. Divergence in labor market institutions is thus found to affect the relative volatility of macroeconomic variables, as noted by Campolmi and Faia (2006) with respect to inflation. Comparison with column (D) suggests that this result is empirically relevant. The model's predictions, of a relative lower volatility in employment and output in countries with more rigid labor markets, is indeed in line with the data. Consistently with empirical evidence, overall results in Table 6 show the importance of heterogeneity in labor market institutions in accounting for international comovement among OECD countries.

\section{Conclusion}

The paper aims at assessing the impact of labor market institutions on business cycle synchronization on theoretical grounds. If the driving forces behind cross-country output correlations have been extensively empirically documented, literature within the New Open Economy Macroeconomy framework does not say much about the analysis of institutions on international comovement. As in Campolmi and Faia (2006), the paper aims at filling this gap. Precisely, we investigate the role of cross-country divergence in labor market institutions in business cycle comovement.

Our results show that asymmetries in the labor market functioning generate persistent cyclical GDP differential in response to aggregate common shocks. Cross-country GDP differentials is mostly attributable to more dampened responses in the economy featured with more stringent labor market institutions. In quantitative terms, divergence in labor market institutions reduces cross-country output correlation, when the model is subject to real and/or monetary shocks. Our overall results show that heterogeneity in labor market regulations matters in accounting for international comovement among OECD countries.

These results open the route to further enlargements. First, it would be interesting to go one step further in the evaluation of the empirical performances of the model, by implementing structural estimation methods as in Ireland (2001) or Kim (2000) (among others). This would allow us to better characterize the degree of heterogeneity among OECD labor markets, and 
to evaluate the quality of fit to the data on a statistical basis. Second, IRFs analysis suggests that adopting more stringent LMI limits the ability of the country to adjust employment and production to world-demand changes occurring with technological and monetary policy shocks. This suggests to tackle the question in normative terms, asking for the "good design" of labor market institutions in terms of welfare analysis. These points are left for further research.

\section{References}

Ambler, S., E. Cardia, and C. Zimmermann (2004): "International Business Cycles: What are the Facts?," Journal of Monetary Economics, 51, 257-276.

Andolfatto, D. (1996): "Business Cycles and Labor-Market Search," The American Economic Review, (1), 112-132.

Backus, D., P. Kehoe, and F. Kydland (1992): "International Real Business Cycles," Journal of Political Economy, 100(4), 745-775.

- (1995): "International Real Business Cycles: Theory versus Evidence," in Frontiers of Business Cycle Research, ed. by T. Cooley, pp. 213-231. Princeton University Press.

Basu, S., And J. Fernald (1997): "Returns to Scale in U.S. Production: Estimates and Implications," Journal of Political Economy.

Basu, S., J. Fernald, and S. Kimball (2006): "Are Technology Improvements Contractionary?," American Economic Review, 96(5), 1418-1448.

BAXter, M. (1995): "International Trade and Business Cycles," in Handbook of International Economics, ed. by N. Holland, vol. 3, chap. 35. Grossman, H. and Rogoff, K.

Baxter, M., and M. Crucini (1995): "Business Cycle and the Asset Structure of Foreign Trade," International Economic Review, 36(4), 821-854.

Baxter, M., and M. Kouparitsas (2005): "Determinants of Business Cycle Comovement: A Robust Analysis," Journal of Monetary Economics, 52, 113-157.

Belot, M., and J. Van Ours (2004): "Does the recent sucess of some OECD countries in lowering their unemployment rates lie in the clever design of their labour market reforms?," Oxford Economic Papers, 56(4), 621-642.

Blanchard, O., and J. Wolfers (2000): "The Role of Shocks and Institutions In The Rise of European Unemployment: The Aggregate Evidence," Economic Journal, 110.

Cahuc, P., And A. Zylberberg (2004): Labor Economics. MiT Press, Cambridge, MA. 
Calvo, G. (1983): "Staggered Prices in a Utility-Maximizing Framework," Journal of Monetary Economics, 12, 383-398.

Campolmi, A., And E. Faia (2006): "Cyclical Inflation Divergence and Different Labor Market Institutions in the EMU," Working Paper 619, European Central Bank.

Chang, Y., And J. H. Hong (2005): "Do Technological Improvements in the Manufacturing Sector Raise or Lower Employment?," Working Paper 05-5, Federal Reserve Bank of Philadelphia.

Chéron, A., And F. Langot (2004): "Labor market search and real business cycles: reconciling Nash bargaining with the real wage dynamics," Review of Economic Dynamics, pp. 476-493.

Christiano, L. (1991): "Modeling the Liquidity Effect of a Money Shock," Federal Reserve Bank of Minneapolis Quarterly Review, 15, 3-34.

Christiano, L., M. Eichenbaum, and C. Evans (1999): "Monetary Policy Shocks: What Have We Learned and to What End?," in Handbook of Macroeconomics, ed. by R. Taylor, and M. Woodford, vol. 1A, pp. 65-148. Elsevier North Holland.

Christoffel, K., K. KÜster, And T. Linzert (2006): "Identifying the role of labor markets for monetary policy in an estimated DSGE model," Working paper 635, European Central Bank.

Christoffel, K., And T. Linzert (2005): "The role of real wage rigidity and labor market frictions for unemployment and inflation dynamics," ECB Working Paper 556.

Corsetti, G., And P. Pesenti (2001): "Welfare and Macroeoconomic Interdependence," Quarterly Journal of Economics, 116(6307), 421-446.

Corsetti, L., L. Dedola, and S. Leduc (2004): "International Risk Sharing and the Transmission of Productivity Shocks," Discussion Paper 4746, CEPR.

Darvas, Z., A. Rose, and G. Szarpary (2005): "Fiscal Divergence and Business Cycle Synchronization : Irresponsibility is Idiosyncratic," Working paper 11580, NBER.

Den Haan, W. Ramey, G., and J. Watson (2000): "Job Destruction and Propagation of Shocks," American Economic Review, 90, 482-498.

Devereux, M., A. Gregory, and G. Smith (1992): "Realistic Cross-Country Consumption Correlations in a Two-Country Equilibrium Business Cycle Model," Journal of International Money and Finance, 11, 3-16.

Duarte, M., and A. Stockman (2005): "Rational Speculation and Exchange Rates," Journal of Monetary Economics, 52(8362), 3-29. 
FARMer, R. (1993): The Macroeconomics of Self-fulfilling Prophecies. MIT Press, Cambridge,MA.

Fonseca, R., L. Patureau, and T. Sopraseuth (2007): "Business Cycle Comovement and Labor Market Institutions in OECD Countries," Working Paper WP-511, Rand Corporation.

Frankel, J., And A. Rose (1998): "The Endogeneity of the Optimum Currency Area Criteria," Economic Journal, 108(449), 1009-1025.

Gali, J. (1999): "Technology, Employment, and the Business Cycle: Do Technology Shocks Explain Aggregate Fluctuations?," American Economic Review, 89, 6249-271.

Ghironi, F. (2006): "Macroeconomic Interdependence under Incomplete Markets," Journal of International Economics, 70, 428-450.

Hairault, J.-O. (2002): "Labor-Market Search and International Business Cycles," Review of Economic Dynamics, 5, 535-558.

Hall, R. (2003): "Wage Determination and Employment Fluctuations," Working Paper 9967, NBER.

Hodrick, R., and E. Prescott (1997): "Post War US Business Cycles: an Empirical Investigation," Journal of Money, Credit and Banking, 29, 1-16.

Hooper, P., And J. Marquez (1995): Exchange Rates, prices and external adjustment in the Unites States and JapanPrinceton, Princeton University Press, Washington D.C.

Hosios, A. (1990): "On the Efficiency of Matching and and Related Models of Search and Unemployment," Review of Economic Studies, 57, 279-298.

ImBs, J. (2001): "Co-Fluctuations," CEPR Discussion Paper 2267, CEPR.

(2004): "Trade, Finance, Specialization and Synchronization," Review of Economics and Statistics, 86(3), 723-734.

Ireland, P. (2001): "Sticky-Price Models of the Business Cycle : Specification and Stability," Journal of Monetary Economics, 47, 3-18.

Kashyap, A., And B. Mojon (2003): Monetary Policy Transmission in the Euro Area: A Study by the Eurosystem Monetary Transmission Network. Cambridge University Press.

Keen, B. D., and Y. Wang (2007): "What is Realistic Value for price Adjustment Costs in New Keynesian Models?," Applied Economics Letter. 
KIM, J. (2000): "Constructing and Estimating a Realistic Optimizing Model of Monetary Policy," Journal of Monetary Economics, 45, 329-359.

Kollmann, R. (2001): "Explaining International Comovement of Output and Asset Returns: The Role of Money and Nominal Rigidities," Journal of Economic Dynamics and Control, 25, $1547-1583$.

Kollmann, R. (2004): "Monetary Policy Rules in an Interdependent World," Discussion Paper 4012, CEPR Discussion Paper.

Kraus, M., And T. LubiK (forthcoming): "The (Ir)relevance of Real Wage Rigidity in the New Keynesian Model with Search Frictions," Journal of Monetary Economics.

Kydland, F., And E. Prescott (1982): "Time To Build and Aggregate Fluctuations," Econometrica, 50, 1345-1370.

Lane, P., and G. Milesi-Ferretti (2001): "Long-Term Capital Movements," NBER Macroeconomics Annual, 16, 73-116.

MaCurdy, T. (1981): "An empirical model of labour supply in a life cycle setting," Journal of Political Economy, (61), 1059-1085.

Milliard, S., A. Scott, And M. Sensier (1997): "The Labour Market over the Business Cycle: Can Theory Fit the Facts?," Oxford review of Economic Policy, 13 (3), 70-92.

Mortensen, D., And C. Pissarides (1999): Job Reallocation, Employment Fluctuations and Unemploymentchap. 18, pp. 1171-1228. Amsterdam: Elsevier Science North Holland.

Nickell, S. (1998): "Unemployment: Questions and Some Answers," The Economic Journal, 108, 1802-816.

Nickell, W. (2006): "The CEP - OECD Institutions Dataset (1960-2004)," Discussion Paper 0759, Centre for Economic Performance.

Obstfeld, M., And K. Rogoff (1995): "Exchange Rate Dynamics Redux," Journal of Political Economy, 103(3), 624-660.

OECD (2004): "Employment Outlook," Discussion paper, OECD, Paris.

Patureau, L. (2007): "Pricing-to-Market, Limited Participation and Exchange Rate Dynamics," Journal of Economic, Dynamics and Control, 31, 3281-3320.

Pissarides, C. (1990): Equilibrium Unemployment Theory. Basil Blackwell, Oxford. 
Poilly, C., And J.-G. SAhuC (2008): "Welfare Implications of Heterogenous Labor Markets in a Currency Area," Manuscript, Banque de France.

Rotemberg, J. (1982): "Sticky Prices in the United States," Journal of Political Economy, 90, $1187-1211$.

Schlagenhauf, D., And J. Wrase (1995): "Liquidity and Real Activity in a Simple Openeconomy Model," Journal of Monetary Economics, 35(3), 431-461.

Schmitt-Grohe, S., and M. Uribe (2003): "Closing Small Open Economy Models," Journal of International Economics, 61, 163-185.

Shimer, R. (2005): "The Cyclical Behavior of Equilibrium Unemployment and Vacancies," American Economic Review, 95(1), 25-49.

Stockman, A., and L. Tesar (1995): "Tastes and Technology in a Two-country Model of the Business Cycle: Explaining International Comovements," American Economic Review, 85(1), 168-185.

TaYlor, J. (1993): "Discretion Vs. Policy Rules in Practice," Carnegie-Rochester Conference Series on Public Policy, 39, 195-214.

Trigari, A. (2004): "Labor Market Search, Wage Bargaining and Inflation Dynamics," Working paper 268, Bocconi University. 


\section{A Data description}

This section provides details regarding sources and variables used to obtain the stylized facts reported in Section 2 and in Section 6. We use data coming from the BSDB OECD database to calculate the cross-country GDP correlation. We use quarterly series of GDP (at factor cost), in volume at constant prices, over the period 1973:2-1998:4. We correct German GDP series for the structural break due to German reunification.

Data inspection for macroeconomic series indeed suggests a structural break on German data, due to the German reunification, that the model cannot account for. Based on the methodology proposed by Milliard, Scott, and Sensier (1997), we detect outliers on the series converted into growth rates. This leads us to identify one outlier (1990:1). The corresponding point in the series taken in growth rate is therefore replaced by averaging the closest growth rates. The GDP series is then converted back into level. ${ }^{22}$

Labor market institutions variables are coming from the database provided by Nickell (2006), based on OECD data. We retain the following variables:

- Employment protection laws (all workers). It is an index that ranges in 1-2, increasing with strictness of employment protection. It consists of the laws, regulations and administrative decisions that constraint the contractual conditions under which a worker can be dismissed; the laws and regulations relating to the compensation an employer is obliged to pay when regulations determining remedies for wrongful or unfair dismissal.

- Net Union Density and Union coverage. Union density is the percentage of employees who are union members. Union coverage refers to the number of workers covered by collective agreements normalized on employment. Both variables are intended to capture the unions' bargaining power.

- Tax wedge. It constitutes the wedge between the real product wage (labor costs per employee normalized on the output price) and the real consumption wage (after tax pay normalized on the consumer price index)This variable (in percent) is equal to the sum of the employer's tax rate (employer's social security contributions as $\%$ of wages and salaries), the direct tax rate (amount of direct taxes as \% of households' current receipts) and the indirect tax rate (total indirect tax as $\%$ private final expenditures).

- Benefit replacement ratio. It is the gross benefit replacement rate. The benefits are a percentage of average earnings before tax. We consider the original benefit replacement rates data published by the OECD. It is defined as the average across the first five years of unemployment for three family situations and two money levels.

\footnotetext{
${ }^{22}$ However, we check that the stylized facts reported in Section 2 are robust to the absence of treatment of German data.
} 
Nickell (2006)'s database delivers information regarding 20 OECD countries. For each country and LMI variable, we take the mean value over the period. We treat the employment protection variable differently from the others, since it is constructed as an index and not as a percent. For the 4 other variables, we build a country-specific synthetic LMI indicator $\left(L M I_{i}\right)$ that averages them. We then calculate two measures of divergence in LMI ("Diff. in LMI" and "Diff. in EPL"), for each country pair $(i, j)$ :

$$
\begin{aligned}
\text { Diff. in } \mathrm{LMI}_{i j} & =\left|L M I_{i}-L M I_{j}\right| \\
\text { Diff. in } \mathrm{EPL}_{i j} & =\left|e p l_{i}-e p l_{j}\right|
\end{aligned}
$$

The country list initially includes 20 OECD countries. We remove Ireland, Norway et Switzerland because of too missing values in the labor market institutions variables. Second, we remove Australia and New Zealand, since they clearly appear as outliers when inspecting the correlation between cross-country GDP correlation and divergence in LMI. This gives us a list of 15 OECD countries: Austria, Belgium, Canada, Denmark, Finland, France, Germany, Italy, Japan, the Netherlands, Portugal, Spain, Sweden, the United-Kingdom and the United-States (105 countrypairs).

The control variables used in Section 2 are the following.

- The volume of bilateral trade ("Bilat. trade) is taken from Andreaw Rose's webpage (http://faculty.haas.berkeley.edu/arose). We take the average value over the last three decades (i.e. over 1974-2004).

- The common language dummy is taken from the CEPII Distance database (http://www.cepii.fr/francgraph/bdd/bddmodeles.htm).

Table 6 reports second-order moments of macroeconomic variables that correspond to the median value over the set of 10 countries included in the Backus, Kehoe, and Kydland (1995) sample (that is, Australia, Austria, Canada, France, Germany, Italy, Japan, Switzerland, UnitedKindom and the United-States), in column (D). Lines ( $a$ ) and (b) of Table 6 reports the volatility of output and employment in a sub-sample of "rigid LMI" countries (median value) relative to that observed in a sub-sample of "flexible LMI" countries (median value). The partition of the 10-country sample into rigid or flexible countries with respect to their labor market functioning obeys the following reasoning. Similarly as in Section 2, we identify the countries as rigid or flexible, using various dimensions of the labor market regulations in place. We rely on information provided by the LMI dataset used in Section 2. This gives us two indicators of the labor market rigidity, for each of the 10 countries of the sample: employment protection and the synthetic LMI. We consider as rigid countries, those whose value for EPL and the synthetic LMI variable 
is larger or equal to the median of the country sample (a high value denoting a more rigid labor market). The opposite reasoning is made for the flexible countries group.

\section{B Complements to the model}

\section{B.1 the household's intratemporal program}

Optimal allocation between national varieties by the domestic household for consumption motives leads to the following demand functions:

$$
\begin{aligned}
C_{1 t} & =\kappa\left[\frac{P_{1 t}}{P_{1 t}^{c}}\right]^{-\zeta} C_{1 t}^{c} \\
C_{2 t} & =(1-\kappa)\left[\frac{e_{t} P_{2 t}^{*}}{P_{1 t}^{c}}\right]^{-\zeta} C_{1 t}^{c}
\end{aligned}
$$

$P_{1 t}$ denotes the price of domestic variety and $P_{1 t}^{c}$ is the consumption price index, both expressed in domestic currency. As well, $P_{2 t}^{*}$ and $P_{2 t}^{c}$ denote the price of the foreign variety and the consumption price level in country 2 respectively, expressed in foreign currency. $e_{t}$ is the nominal exchange rate, defined as the price of foreign currency. As may be inferred from equation (32), the law of one price holds in the model.

Within each national variety, optimal allocation leads to the following demand functions made by the domestic household for a variety $z$ produced in the home and in the foreign country respectively:

$$
\begin{aligned}
& c_{1 t}(z)=\left[\frac{p_{1}(z)}{P_{1 t}}\right]^{-\eta} C_{1 t} \\
& c_{2 t}(z)=\left[\frac{e_{t} p_{2}^{*}(z)}{P_{2 t}}\right]^{-\eta} C_{2 t}
\end{aligned}
$$

The associated price indices in county 1 are given by:

$$
\begin{aligned}
& P_{1 t}=\left[\int_{0}^{1} p_{1 t}(z)^{1-\eta} d z\right]^{\frac{1}{1-\eta}} \\
& P_{2 t}=\left[\int_{0}^{1}\left[e_{t} p_{2 t}^{*}(z)\right]^{1-\eta} d z\right]^{\frac{1}{1-\eta}} \\
& P_{1 t}^{c}=\left[\kappa^{\frac{1}{\zeta}} P_{1 t}^{1-\zeta}+(1-\kappa)^{\frac{1}{\zeta}}\left(e_{t} P_{2 t}^{*}\right)^{1-\zeta}\right]^{\frac{1}{1-\zeta}}
\end{aligned}
$$

Similar expressions hold in the foreign country.

\section{B.2 Deriving the mark-up rates expression}

In a monopolistic setting, price-maker firms optimally break the usual equality between sale price and unit cost, by setting a positive mark-up rates over marginal costs, which is defined (for a 
firm $z$ in country $i$ ) as follows:

$$
p_{i t}(z)=\left(1+\mu_{i t}(z)\right) C m_{i t}(z)
$$

with $C m_{i t}(z)$ the marginal cost of production. Deriving the expression for the mark-up rates requires to obtain the total production cost and its derivative, the unit cost.

We abstract here from decisions relative to vacancies posting or investment. First step consists in determining the minimal total production cost for a given amount of production. We then solve the following program (suppressing the $z$ index for notational simplicity):

$$
\begin{aligned}
\min _{\left\{n_{i t} h_{i t}, k_{i t}\right\}} C T_{i t} & =P_{i t}^{c}\left(1+\tau_{i}^{f}\right) w_{i t} n_{i t} h_{i t}+P_{i t}^{c} z_{i t} k_{i t} \\
\text { s.t } \quad y_{i t} & =A_{i t} k_{i t}^{\alpha}\left(n_{i t} h_{i t}\right)^{1-\alpha} \geq \bar{F}
\end{aligned}
$$

with $z_{i t}$ the rental price of capital. This yields the following optimal unitary cost:

$$
C m_{i t}=P_{i t}^{c} z_{i t}^{\alpha}\left[\left(1+\tau_{i}^{f}\right) w_{i t}\right]^{1-\alpha}(1-\alpha)^{\alpha-1} \alpha^{-\alpha}
$$

The instantaneous profit of a country-1 firm can therefore be written as:

$$
\pi_{1 t}^{f}=p_{1 t} y_{1 t}-C m_{1 t} y_{1 t}-\omega_{1} P_{1 t}^{c} v_{1 t}-P_{1 t} i_{1 t}-P_{1 t}\left(c p_{1 t}+c i_{1 t}\right)
$$

Denoting $\nu_{1 t}$ the multiplier associated to the demand function for the firm's variety (equation (17)), the first-order conditions related to the optimal choice for $y_{1 t}$ is:

$$
p_{1 t}-\nu_{1 t}-P_{1 t}^{c} \frac{c p_{1 t}^{1}}{y_{1 t}}=C m_{1 t}
$$

Given the definition of the mark-up rate (equation (37)), one can derive the optimal expression for the mark-up rate the domestic firm can extract:

$$
\mu_{1 t}=\frac{\nu_{1 t}+P_{1 t}^{c} \frac{c p_{1 t}}{y_{1 t}}}{p_{1 t}-\nu_{1 t}-P_{1 t}^{c} \frac{c p_{1 t}}{y_{1 t}}}
$$

Similar expressions hold for the foreign country.

\section{B.3 Solving the labor contract}

The marginal discounted value of a match for a firm in country 1 (measured in terms of domestic currency) is defined by:

$$
J_{1 t}^{F}=\frac{\partial \mathcal{W}\left(\mathcal{S}_{1 t}^{F}\right)}{\partial N_{1 t}}
$$

that becomes, given the firm's optimizing problem presented in Section 3.3.2:

$$
J_{1 t}^{F}=-P_{1 t}^{c} w_{1 t} h_{1 t}\left(1+\tau_{1}^{f}\right)+\nu_{1 t}(1-\alpha) \frac{Y_{1 t}}{N_{1 t}}+\left(1-s_{1}\right) \frac{\omega_{i}}{q_{i t}}+\left(1-s_{1}\right) \beta E_{t}\left[\frac{\lambda_{1 t+1}}{\lambda_{1 t}} J_{1 t+1}^{F}\right]
$$


As well, let $J_{1 t}^{H}$ define the marginal discounted value of a match for the worker as:

$$
J_{1 t}^{H}=\frac{\partial \mathcal{V}\left(\mathcal{S}_{1 t}^{H}\right)}{\partial N_{1 t}}
$$

Given the household's optimizing problem detailed in Section 3.3.1 and the employment law of motion (3), it becomes:

$$
J_{1 t}^{H}=\kappa^{n} \frac{\left(1-h_{1 t}\right)^{1-\xi}}{1-\xi}+\lambda_{1 t} P_{1 t}^{c}\left[w_{1 t} h_{1 t}\left(1-\tau_{1}^{d}-b_{1 t}\right)\right]+\left(1-s_{1}-\phi_{1 t}\right) \beta E_{t} J_{1 t+1}^{H}
$$

The Nash-bargaining criterion that firms and household attempt to solve is given by:

$$
\max _{w_{1 t}, h_{1 t}}\left(\lambda_{1 t} J_{1 t}^{F}\right)^{\epsilon}\left(J_{1 t}^{H}\right)^{1-\epsilon}
$$

with $\lambda_{1 t} J_{1 t}^{F}$ the marginal value of the match for the firm, expressed in terms of the household's marginal utility of wealth. $0<\epsilon<1$ denotes the firm's share of the value of a job that forms in the search equilibrium. The first-order condition associated with $w_{1 t}$ leads to the following surplus sharing-role:

$$
J_{1 t}^{H}=\frac{1-\epsilon}{\epsilon} \frac{1-\tau_{1}^{d}}{1+\tau_{1}^{f}} \lambda_{1 t} J_{1 t}^{F}
$$

As shown by equation (43), labor taxes, whether they are paid by the employer or by the employee, reduce the surplus that is shared through the Nash-negotiation. 